\title{
Clinical Application of Stem/Stromal Cells in COPD
}

\author{
Sara Rolandsson Enes, Juan J. Uriarte, \\ Robert A. Pouliot, and Daniel J. Weiss
}

\subsection{Introduction}

Chronic obstructive pulmonary disease (COPD) is a progressive life-threatening disease that is significantly increasing in prevalence. The World Health Organization (WHO) predicts that COPD will become the third leading cause of death worldwide by 2030 [1-3]. There is currently no cure for this disease, and smoking cessation remains the most prominent intervention [4]. Because of the lack of effective curative pharmaceutical options and the increase in prevalence, extensive efforts have been devoted to the development of new strategies for cell replacement and tissue remodeling in COPD. So far, most focus has been on mesenchymal stromal cell (MSC) therapy. MSC are theoretically ideal candidates for cell therapeutic approaches because of their low or absent constitutive HLA class I and II expression, allowing allogeneic administration of MSCs obtained from normal healthy

\section{S. R. Enes}

Department of Medicine, Larner College of Medicine, University of Vermont, Burlington, VT, USA

Department of Experimental Medical Science, Faculty of Medicine, Lund University, Lund, Sweden

\footnotetext{
J. J. Uriarte · R. A. Pouliot · D. J. Weiss $(\bowtie)$

Department of Medicine, Larner College

of Medicine, University of Vermont,

Burlington, VT, USA

e-mail: Daniel.Weiss@med.uvm.edu
}

volunteers, and their immunosuppressive and antibacterial properties [5, 6]. In this chapter, we will examine in detail the biological rationale for use of MSCs in COPD, clinical trials, and the current challenges for implementing this approach as a potential therapy for COPD.

\subsection{COPD-A Heterogeneous Lung Disease with No Curative Treatment Available}

COPD is a progressive lower respiratory condition, which has a massive impact on public health worldwide. Increasing in prevalence, COPD is currently responsible for over 120,000 US deaths annually and is expected to become the third leading cause of death globally in the next few years [7]. COPD is most often associated with longterm smokers over the age of 40 and is thought to be driven by abnormal tissue response(s) to inhaled toxic particles over time. The life expectancy of continuous cigarette smokers is at least 10 years shorter than nonsmokers and the absolute risk of developing COPD among this population has been estimated to be $15-30 \%$ [8]; however, there is evidence for significant underdiagnosis $[9,10]$. The most common symptoms of COPD are chronic bronchitis (persistent cough with chronic mucus production), dyspnea (shortness-of-breath), wheezing, and chest tightness. As a progressive disease, these symptoms get worse 
over time. Current treatments, most importantly smoking cessation, are part of a delay strategy to slow down the physiological disease progression. These physiologic changes all contribute to the impairment of efficient breathing and include: the gradual loss-of-elasticity of the lung tissue leading to collapse of airway and alveolar sacs, weakening-to-rupture of alveolar septal walls, enlargement of segmented airspace, loss of gasexchange surface area, increased mucus production, airway plugging, and airway narrowing driven by swelling and fibrosis (Fig. 6.1). COPD is a complex pathology with a diverse spectrum of clinical phenotypes, comorbidities, and treatment profiles $[11,12]$. The GOLD criteria have been widely utilized to help standardize the COPD definitions and treatment guidelines; however, they do not fully encompass the diversity of COPD phenotypes [13, 14].

The treatments available to patients diagnosed with COPD are not curative and cannot completely stop disease progression; however,
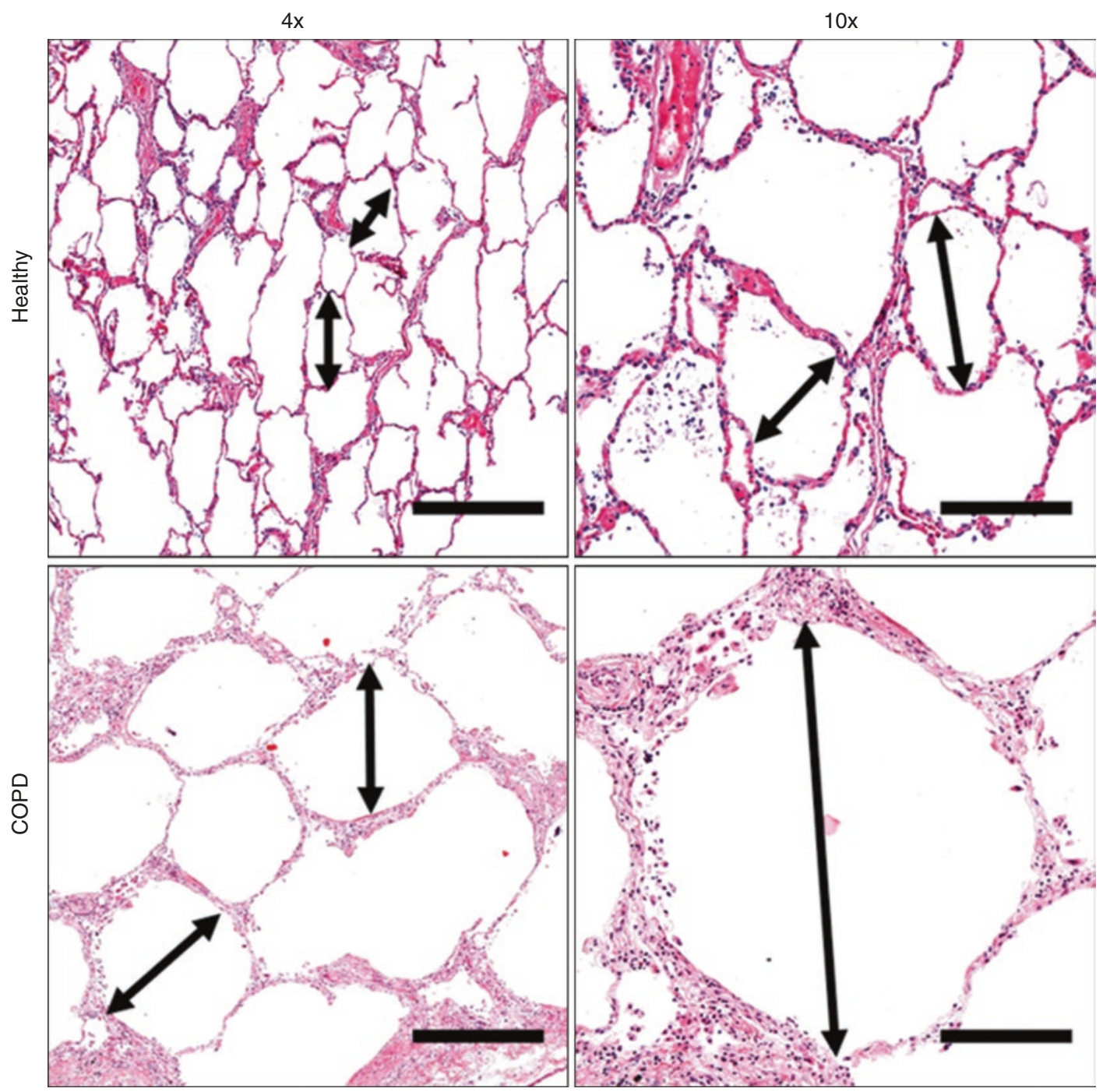

Fig. 6.1 Photomicrographs of lung tissue obtained from healthy and chronic obstructive pulmonary disease (COPD) subjects stained with hematoxylin-eosin. Arrows indicate alveolar space (side-to-side alveolar wall distance). Scale bars at $4 \times$ magnification represent $500 \mu \mathrm{m}$ and at $10 \times$ magnification $200 \mu \mathrm{m}$ 
they are key to slowing disease progression and importantly to improve quality of life. The most important intervention at any stage is the cessation of smoking and/or limitation of exposure to other identified environmental risk factors. Symptomatic treatment throughout disease progression often relies on bronchodilators, which are inhaled beta-agonists or muscarinic antagonists. Early-stage individuals will most often be treated with short-acting bronchodilator therapies (SABA/SAMA); however, as the disease progresses treatment will need to incorporate long-acting drugs that affect these receptors (LABA/LAMA). Unfortunately, bronchodilators can only partially resolve lung hyperinflation in emphysema [15], becomingly increasingly less effective as the disease progresses. Inhaled corticosteroids (ICS), often used to treat acute respiratory exacerbations, work by interfering with the transcription pathways of key inflammation genes; however, this treatment does not always work and unfortunately can have little to no longterm benefits [16].

In addition to direct toxic effects of cigarette smoke on lung epithelial cells, there is increasing appreciation that altered or aberrant immune cell signaling significantly contributes to much of the irreparable tissue damage. Smokers with undiagnosed COPD normally experience lowlevel infiltration of inflammatory cells into the large airways and peripheral lung parenchyma and have what is increasingly recognized as early disease. In individuals with diagnosed COPD, the inflammatory process is amplified and prolonged leading to many of the tissue-remodeling events associated with chronic bronchitis and emphysema; hallmarks of COPD [17]. For example, in smoking-induced emphysema, chronically activated macrophages have been found to express upregulated levels of several proteinases and matrix metalloproteinases (MMPs) in both human smokers and in mouse models of cigarette exposure [18]. Macrophages also play a crucial role in triggering the initial immune response in responding to smoking induced inflammation. Alveolar macrophages are usually in a quiescent state and actually work to suppress the adaptive immune system in the healthy lung; however, in chronic inflammatory situations alveolar macrophages are the main source of proinflammatory amplification and play a significant role in causing an influx of other immune cells [19].

Ultimately, the disease progresses to a point where gas exchange is limited by the tissue damage and extent of hyperinflation. In many cases invasive surgical interventions are the only option; these include endobronchial valve insertion, bullectomy, lung volume reduction surgery, and lung transplantation [20]. Lung volume reduction surgeries can successfully address some issues with hyperinflation in selected patients by returning some of the mechanical advantage of normal breathing. However, invasive surgeries are associated with high morbidity and operative mortality [21-23], especially in late-stage COPD patients who are often poor targets for surgical intervention. For some patients with end-stage COPD, lung transplantation is the only option. However, this approach offers its own unique challenges including rejection risk, requirement for immunosuppression, and the limited supply of donor lungs. While transplanted lungs can certainly facilitate better gas exchange than severe COPD lungs, the benefits are balanced by the risks, as the 5 years survival of transplant recipients is only around 50\% [24-27]. At present, there are no true curative treatments that can stop the progression of COPD, thus new therapeutic strategies are needed. Advances in cell-based therapies provide a platform for development of new therapeutic approaches in COPD. At this moment, much focus has been given to MSC cell-based therapies, mainly because of their immunomodulatory properties.

\subsection{MSC-Based Therapy in Human Clinical Trials of COPD and Emphysema}

The promising results in animal models have translated into clinical trials for treatment of COPD and emphysema. Searching on the ClinicalTrials.gov database for trials listed through November 28 2018, using the keywords "COPD" and "stromal cell"; "COPD" and "mesenchymal 
stromal cell"; "COPD" and "mesenchymal stem cell"; "Emphysema" and "stromal cell"; "Emphysema" and "mesenchymal stromal cell"; and "Emphysema" and "mesenchymal stem cell", identified 18 studies of human clinical trials. So far, four of the studies have been completed and had their results published in the PubMed database, four are still in the process of recruiting patients, three of them are active but not recruiting patients, three have an unknown status, and four of them have been withdrawn [28]. This section will be focusing on the clinical studies that have been completed and for which results have been published (Table 6.1).

In 2011, Ribeiro-Paes et al. conducted the first clinical investigation evaluating the safety of using bone marrow-derived mononuclear cells (BMMC) in four patients with advanced-stage COPD (NCT01110252). Autologous BMMC were collected after 3 days of granulocyte colony stimulating factor (G-CSF) stimulation, and BMMC were isolated using Ficoll-Hypaque Premium $^{\mathrm{TM}}$. The cells were further resuspended in albumin saline solution (ASS) at a final concentration of $1 \times 10^{8}$ mononuclear cells $/ \mathrm{mL}$, and intravenously administered directly to the patients without freezing or in vitro culture procedures. The patients were evaluated by several pulmonary function tests, including forced vital capacity (FVC), forced expiratory volume in $1 \mathrm{~s}$ (FEV1), and partial pressure of carbon dioxide $\left(\mathrm{PaCO}_{2}\right)$. [29] Importantly, due to the small size of this study, lack of controls, and the lack of statistical analysis no clear conclusions can be drawn from these results. Furthermore, the cells used in this study were heterogeneous mononuclear cells isolated from bone marrow aspirates, and not MSCs, and therefore this study cannot be considered as the first MSC study for treatment of COPD patients.

In 2013, Weiss et al. performed a prospective, randomized, double-blind, placebo-controlled industry-sponsored trial evaluating the safety and the efficacy of intravenous allogeneic MSCs (NCT00683722). The study enrolled 62 patients (40-80 years of age), from six different centers, with moderate-to-severe COPD (GOLD II or III). The patients were randomized into two groups, where the first group received non-HLAmatched allogeneic MSCs and the second group

Table 6.1 Completed clinical trials investigating MSCs for COPD treatment

\begin{tabular}{|c|c|c|c|c|c|c|c|}
\hline NCT number & Study design & $\begin{array}{l}\text { No. } \\
\text { patients }\end{array}$ & Route & No. of cells & $\begin{array}{l}\text { Follow up } \\
\text { (months) }\end{array}$ & $\begin{array}{l}\text { Primary } \\
\text { outcome }\end{array}$ & Comments \\
\hline NCT01110252 & $\begin{array}{l}\text { Non- } \\
\text { randomized } \\
\text { Phase I } \\
\text { Unicenter } \\
\text { Single group } \\
\text { Open label }\end{array}$ & 4 & IV & $\begin{array}{l}1 \times 10^{8} / \mathrm{mL} \\
(30 \mathrm{~mL} \text { total })\end{array}$ & 12 & $\begin{array}{l}\text { Safety } \\
\text { FVC } \\
\text { FEV1 } \\
\text { VC }\end{array}$ & BMMC \\
\hline NCT00683722 & $\begin{array}{l}\text { Randomized } \\
\text { Phase II } \\
\text { Multicenter } \\
\text { Parallel } \\
\text { assignment } \\
\text { Placebo } \\
\text { controlled }\end{array}$ & 62 & IV & $\begin{array}{l}100 \times 10^{6} \mathrm{BM}-\mathrm{MSC} / \\
\mathrm{kg} \\
\text { (four infusions total) }\end{array}$ & 24 & Safety & \\
\hline NCT01306513 & $\begin{array}{l}\text { Prospective } \\
\text { Phase I } \\
\text { Unicentric } \\
\text { Single group } \\
\text { Open label }\end{array}$ & 10 & IV & $\begin{array}{l}1-2 \times 10^{6} \text { BM-MSCs/ } \\
\mathrm{kg} \\
\text { (two infusions total) }\end{array}$ & 12 & $\begin{array}{l}\text { Safety } \\
\text { Tolerability }\end{array}$ & Prior LVRS \\
\hline NCT01872624 & $\begin{array}{l}\text { Non- } \\
\text { randomized } \\
\text { Parallel } \\
\text { assignment } \\
\text { Open label }\end{array}$ & 10 & IB & $\begin{array}{l}10^{8} \text { MSCs in } 30 \mathrm{~mL} \\
\text { saline }\end{array}$ & 4 & $\begin{array}{l}\text { Safety } \\
\text { Absence of } \\
\text { deficits }\end{array}$ & $\begin{array}{l}\text { EBV } \\
\text { insertion }\end{array}$ \\
\hline
\end{tabular}


received placebo (vehicle) treatment. MSCs were obtained from unrelated donors, expanded in vitro for a total of five passages in culture medium supplemented with $10 \%$ FBS followed by cryopreservation using human serum albumin and $10 \%$ DMSO. After thawing, MSCs or vehicles were systemically infused four times (at day $0,30,60$, and 90) and the patients were followed for 2 years. The patients were evaluated by ECG, exacerbation records, FEV1, FVC, total lung capacity, dyspnea assessment (Borg scale), and 6-min walk test. Systemic inflammation was measured by circulating levels of inflammatory cytokines such as tumor necrosis factor (TNF)alpha, interferon (IFN)-gamma, IL-10, and C-reactive protein (CRP). All 62 patients completed all four infusions, and $63 \%$ of the patients receiving MSC infusion and $84 \%$ of the patients in the placebo group completed the full protocol. The infusions were well tolerated and no severe or fatal adverse events were observed during the MSC or vehicle administration. No significant differences in FEV1, FVC, and total lung capacity were seen between the groups. Nor were differences in 6-min walk test or dyspnea assessment observed between the two groups. For most of the circulating inflammatory cytokines no significant differences were seen between the MSCtreated patients and the vehicle group. However, a decrease in the CRP level in patients treated with MSC compared to their baseline CRP levels was observed. The most important finding in this study was that MSC administration was safe in an older population of patients with moderate-tosevere COPD [30].

Stolk et al. performed a Phase I, prospective, open-label study (NCT01306513) where they aimed to assess the safety and feasibility of intravenously infused bone marrow-derived MSCs for ten patients with severe emphysema that had serial lung volume reduction surgeries (LVRS). During the first LVRS bone marrow was aspirated. MSCs were isolated from the bone marrow aspirates and expanded in vitro (passage 1-3) followed by cryopreservation. At three and four weeks prior to the second LVRS, MSCs were intravenously administered to the patients at two different occasions. Spirometry, gas transfer, lung volumes, and lung densitometry were evaluated at baseline and at the 12 months follow-up. Seven patients completed the full protocol. Three patients were withdrawn from the study due to problem aspirating bone marrow, no MSC growth, or persistent air leak after the first LVRS. No toxicity after the MSC infusions was observed and the patients did not report any symptoms that were considered related to the treatment. At 12 months follow-up, a significant increase in FEV1 and body weight was observed compared to baseline levels. However, if changes in FEV1 and body weight was due to MSC administration or to the surgeries remain unknown, since this study protocol did not include a control group. Importantly, no signs of increased pulmonary fibrosis were observed when lung tissue was evaluated by both histology and CT-derived lung density [31].

de Oliveira et al. combined MSC administration with one-way endobronchial valve (EBV) insertion [32]. This study was a prospective, patient-blinded, placebo (vehicle)-controlled, phase I study on ten patients with advanced heterogeneous emphysema (NCT01872624). de Oliveira et al. aimed to investigate the safety of combining EBV insertion with intrabronchial MSC administration. The authors hypothesized that combining intrabronchial MSC administration with EBV would reduce the inflammation, a common side effect of EBV placement. This study, however, was not designed to investigate MSC as a treatment for COPD, but rather specifically to investigate if MSC treatment would enhance EBV placement by reducing the underlying inflammation. Therefore, the secondary aim was to investigate if MSC administration reduced the systemic inflammation. Mononuclear cells (MNCs) were isolated from $60 \mathrm{~mL}$ bone marrow aspirate collected from the iliac crest of a single healthy donor using density-gradient centrifugation. MNCs were cultured at a density of $1 \times 10^{5}$ cells per $\mathrm{cm}^{2}$ in Iscove's Modified Dulbecco's Medium supplemented with $15 \%$ fetal bovine serum, penicillin, and streptomycin at $37{ }^{\circ} \mathrm{C}$, $5 \% \mathrm{CO}_{2}$ for generation of MSCs. MSCs were immunophenotyped and samples were taken for microbiological and cytogenetic testing. MSCs were harvested at passage three or four, diluted 
in saline solution, and placed in infusion bags. Right before EBV insertion $10^{8}$ MSCs (in $30 \mathrm{~mL}$ saline) were administered to five of ten patients using a video bronchoscope with a $2.8-\mathrm{mm}$ instrument channel. The patients in the vehicle group received saline. In both groups, the infusions were performed in the region where the EBVs were supposed to be placed (the segmental or subsegmental bronchus of all branches of the target lobe). Immediately after the MSC administration or vehicle administration and EBV insertion, a chest radiograph was performed to confirm the EBV placement. For the following 2 days, the patients were evaluated for body temperature, blood pressure, oxygen saturation, heart, and respiratory rates. Arterial blood gas, complete blood count, urea, creatinine, glucose, and electrolytes were evaluated at day $0,1,7,30$, and 90. Chest CT scans were performed at day 0,30 , and 90 . Circulating levels of inflammatory cytokines were assessed in serial blood samples obtained throughout the study period. Efficacy was evaluated as improvement from baseline in FEV1, FVC, FEV1/FVC, total lung capacity, single-breath carbon monoxide diffusing capacity, the body mass index, airway obstruction, dyspnea, exercise index, and health-related quality of life (St. George's Respiratory Questionnaire). All ten patients completed the full protocol. The MSC administration was well tolerated and all patients tolerated the EBV insertion but one, who developed pneumonia, pneumothorax, empyema, and respiratory failure. No severe adverse events were seen in the group receiving MSC, but $40 \%$ in the MSC group and $60 \%$ in the placebo group experienced adverse events during the study period, and importantly none of the adverse events was reported to be related to the MSC administration. No difference in toxicological or lung function parameters such as FEV1, FVC, and total lung capacity were observed between the groups. In accordance with data reported by Weiss et al. [30] the MSC treated group had significantly reduced levels in CRP at day 30 and 90 post administration. Patients receiving MSC infusions were reported to have a significant decrease in the St. George's Respiratory Questionnaire scores compared to the placebo group at day 90 post administration. The authors concluded that intrabronchial MSC administration in combination with EBV insertion appears to be safe in patients with severe heterogeneous emphysema. Furthermore, in this study MSC administration tended towards decreased circulating CRP levels; however, due to the low number of recruited patients and the limited follow-up period it was not possible to evaluate if MSC treatment altered the efficiency of the EBV placement or the subsequent clinical COPD course. [32].

Finally, Armitage et al. recently published a single site, phase I study that was not listed at the NIH ClinicalTrials.gov database, rather only in the Australian clinical trials registry (number 12614000731695), which aimed to investigate the distribution of intravenously infused MSCs into COPD patients. Nine patients with mild-tosevere COPD (GOLD I-IV) received infusion of low passage allogenic bone marrow-derived MSCs radiolabeled with indium-111, followed by a second infusion of unlabeled MSCs one week post the first administration. In similarity with the other clinical trials, all patients tolerated the MSC infusions well and no infusional or short-term adverse effects were reported. Following the first infusion, labeled MSCs were detected in the lungs within 30 min by computed tomography (CT) scan, and remained detectible $24 \mathrm{~h}$ after the infusion. After $24 \mathrm{~h}$, indium-111 was detected in spleen, liver, and bone marrow up to 7 days after infusion. Moreover, $4 \mathrm{~h}$ after the first infusion the patients were assessed by single-photon emission computed tomography (SPECT) to evaluate MSC localization within the lungs. Furthermore, the amount of indium-111 positively correlated with the baseline FEV1 and the diffusing capacity of the lung for carbon monoxide. In addition, this study further aimed to investigate systemic inflammation following the MSC infusion. The authors were not able to detect IL-1 beta, IL-10, IL-12p70, or IL-17A; however, increased circulating levels of CRP were detected at $1 \mathrm{~h}$ and up to 2 days after MSC administration. Interestingly, this study suggests that MSC infusion shifted the balance towards a more anti-inflammatory profile, as the number of circulating regulatory T-cells were increased 
7 days after MSC administration and the proportion of dendritic cells were altered, favoring plasmacytoid dendritic cells [33].

Current clinical trials that aimed to evaluate the effect of MSC administration in COPD patients differ in a wide range of factors such as routes of administration, number of MSC administered, number of administrations, use of fresh MSCs or culture-expanded MSCs. Furthermore, all the investigations discussed above, were phase I-II studies that were underpowered in order to detect potential efficacy and no improved pulmonary function or respiratory quality of life was observed. Although the primary end-point was safety and all studies reported that MSC administration was well tolerated and no toxicity was observed, further studies, both clinical and preclinical, are needed to better understand potential therapeutic efficacy of MSCs in COPD.

\subsection{The Hurdles That Need to Be Overcome}

Despite increasing number of preclinical studies demonstrating that MSC administration could prevent or treat experimental COPD and emphysema [34-50], clinical studies have not been able to reproduce the preclinical results, and to date no efficacy or significantly improved pulmonary function in COPD patients have been observed. In this section, we will be discussing some of the challenges in the field and the hurdles that need to be overcome in order to improve the efficacy of MSC therapy in COPD [51].

\subsubsection{Standardization of MSC Cell Culture Conditions}

MSCs are known to be a heterogeneous cell population $[52,53]$, containing subpopulations that have been demonstrated to be functionally different from each other $[54,55]$. Many of the phenotypic and functional differences depend on differences in culture conditions, individual donors, the harvest site, and the tissue source [56-59]. This makes it difficult to compare results between different studies, both preclinical and clinical, and importantly it hinders progression in the field. Efforts should therefore be concentrated on developing standardized MSC isolation methods and culture conditions. In 2006, the International Society for Cellular Therapy published a position paper in order to address this issue. In this article, they defined minimal suggested criteria for cultured human MSCs [60]. Since this position paper by Dominici et al. was published it has been updated once in 2012 [6], but the MSC field has advanced and today MSCs are isolated from different organs and tissues and therefore these minimal criteria urgently need to be modified and updated.

To date, bone marrow-derived MSCs are the most widely investigated, but preclinical studies have demonstrated that MSCs with immuneregulatory and regenerative properties can be isolated from other tissues such as adipose tissue, umbilical cord, and lung [58, 61-66]. A large body of data demonstrates that MSCs execute their therapeutic effects through a spectrum of paracrine activities, and interestingly preclinical data suggest that MSCs isolated from different tissues have different secretome profiles [57, 67]. It is also important to realize that primary MSCs change phenotype when they are isolated from their native tissue and plated on a plastic culture dish [56]. The bona-fide MSC, which are thought to be small and quiescent, noncycling cells in vivo, changes phenotype into a spindle-shaped and active proliferating and secretory cell in culture [56, 68]. At early passages, MSCs have a high proliferation rate but as their time in culture progresses their proliferation rate declines and they finally enter a senescence stage [69-71]. Also the morphology is changed during culture expansion, MSCs in early passages have a thin spindle-shaped morphology, but at higher passages MSCs tend to become larger and more flattened cells with an irregular shape $[56,70]$. Moreover, MSCs have been reported to accumulate DNA damage during in vitro expansion, which could potentially lead to tumorigenesis upon implantation [72, 73]. Importantly, tumor development was not observed in any of the clinical studies using MSC as treatment for 
COPD and/or emphysema patients, although longer follow-up is necessary [29-32].

Furthermore, the biological properties of MSCs can also be strongly influenced by the cell culture medium. Cell culture media are often supplemented with serum, and most often fetal bovine serum (FBS) is used. The use of FBS has several disadvantages, especially in clinical settings. First, the possibility of contamination with pathogens such as prions and viruses and the potential immune reaction to bovine proteins. Second, lot-to-lot variation between different FBS batches might induce differences in MSC behavior such as proliferation rates and differentiation potential, and make it difficult to standardize methods and reproducibility of results $[56,74,75]$. Human platelet lysate (HPL) is as an alternative to FBS in clinical settings. HPL has the advantages of containing non-animal products and therefore no risk of xenogeneic infections and immune rejection. On the other hand, HPL is a human product and has the potential to transmit human diseases such as hepatitis B and $\mathrm{C}$, and human immune deficiency virus (HIV). In similarity with FBS, HPL also brings the disadvantage of having lot-to-lot variation [75, 76]. A third option would be to use serum-free cell or synthetic culture media. These media are highly promising, but more studies are needed in order to have evaluate their utility for producing clinical grade-MSCs. Recently, Lensch et al. demonstrated that MSCs had a higher proliferation rate when growing in xeno-free medium which resulted in a greater viable cell yield compared to standard FBS containing culture medium [77]. Nevertheless, further studies are needed in order to evaluate if the in vivo biological properties of MSC are altered when expanded in the in vitro setting.

Another factor that may influence the biological function of MSCs is the freezing and thawing of cells before administrated to patients. The current model for allogeneic MSC use is to expand cells on plastic culture dishes following harvest and isolation from bone marrow or other source and cryopreserve the cells until usage. When it is time for administration, cells are thawed, washed, and directly administered to the patients most commonly through intravenous infusions [78]. However, a number of studies have demonstrated that MSCs that have been freeze-thawed have impaired functional properties. Francois et al. reported that cryopreserved MSCs had impaired immunosuppressive properties [78]. In accordance with these results, Moll et al. published an article where they demonstrated that freezethawed MSCs had a reduced responsiveness to proinflammatory stimuli and an impaired production of anti-inflammatory mediators [79]. Minor effects on gene expression of freeze-thawed MSCs compared to continuously cultured MSCs have been observed. However, the alterations in gene expression between different donors were larger than the effects of cryopreservation [80]. Although there is a practical need for expanding and cryo-banking cells for therapeutic use [79], most preclinical studies have been performed using log phase of growth MSC. There are studies, some of them discussed above, which demonstrated that freeze-thawing procedure alters the biological properties of MSC. Francois et al. found that during the thawing process a heat-shock stress response was initiated that was associated with the impaired immunosuppressive properties of MSC. Interestingly, this response was reversible and cells were recovered after $24 \mathrm{~h}$ of culture [78]. These results imply that cryopreservation and banking of cells might be possible, as long as the cells are allowed to recover in culture before use. The study by Cruz et al. further supports the potential of using freeze-thawed cells for clinical trials. In this study, the authors compared the therapeutic effect of continuously cultured versus freshly thawed bone marrow-derived MSCs in an Aspergillus hyphal extract (AHE) exposed asthma mouse model, and found no difference in therapeutic effect between the two groups [81].

Utilizing plastic culture dishes are by far the most traditional way of cultivating and expanding MSC; however, alternative culture systems have been developed that might mimic the in vivo situation more compared to the more traditional $2 \mathrm{D}$ cultivation on plastic. The use of alternative threedimensional cell culture systems can hopefully contribute to narrowing the gap between preclinical and clinical research. Different groups 
have studied the possibility to grow MSCs on plastic culture dishes coated with extracellular matrix molecules (ECM) such as collagen and fibronectin [82, 83]. ECM is a three-dimensional network composed of noncellular structures that play an important role within the lung, not only by providing structural support and adding stability but also as a bioactive environment that can influence cellular responses [84]. Engler et al. demonstrated that changing the elasticity of the ECM that MSCs were grown on significantly affected the MSC phenotype. MSCs grown on a stiffer ECM differentiated towards the osteoblast lineage, whereas MSCs grown on a softer ECM differentiated towards the adipocyte lineage [85]. The MSC differentiation potential could also be altered by changing the cross-linking of the collagen fibers [86]. In addition, modifications of the geometric shape, cell density, and cell size have been implicated in the differentiation potential of MSC [87, 88]. Interestingly, McMurray et al. developed a nanoscale surface that maintained the phenotype and multilineage potential of longterm cultured MSCs [89]. How the ECM environment affects the MSC therapeutic behavior, especially in a fibrotic or emphysematous COPD lung, is currently a largely untouched area that will most likely play a pivotal role in the development of successful MSC-based therapies.

A different approach of the three-dimensional cultures is the usage of the hanging drop model. In conformity with primary MSCs, culturing MSCs using the hanging drop method resulted in nondividing cells [90], but an increased potential to differentiate towards osteoblast and adipocyte lineages was also demonstrated [91]. Another strategy that has been used for MSC expansion relies on culturing MSCs in 3D scaffolds (decellularized lung tissue or synthetic scaffolds) [9294]. In this system, cultivation on a plastic surface could be avoided, but a perfusion-based bioreactor system is required [56]. Studies have shown that MSCs cultured in lung ECM hydrogels have enhanced viability and increased expression of Sox 2 and Oct 4 compared to cells grown on plastic [95]. Furthermore, changes in secretion of cytokines including IL-1Ra, VEGF, G-CSF, FGF, and HGF have been demonstrated in MSCs grown in 3D culture compared to $2 \mathrm{D}[96,97]$. Taken together, the traditional way of cultivating MSCs as monolayer on a plastic surface may result in MSCs with a different phenotype compared to MSCs expanded in three-dimensional culture systems. However, whether cultivating MSCs on ECM coating, in scaffolds, or in hanging drops increases the beneficial effects when used for clinical settings remains to be evaluated and further studies are needed.

It is well known that oxygen levels can affect cell functions, such as differentiation, cytokine production, and proliferation [98-101]. Furthermore, it is also known that different adult tissues experience a wide range of oxygen levels [102] and that severe pathological inflammation can cause hypoxia, reduced $\mathrm{pH}$, and oxidative stress [103, 104]. Nevertheless, MSCs tend to be cultured at atmospheric oxygen levels (20-21\% $\mathrm{O}_{2}$ ) which do not reflect the microenvironment they normally reside in, or the microenvironment they will encounter when administered into the diseased lung [102]. Culturing MSCs at oxygen levels that more closely represent their in vivo situation have a huge impact on MSC behaviors. Lennon et al. observed that MSCs grown at lower oxygen levels had a greater number of colony-forming cells and proliferated at a higher rate compared to MSCs grown at higher oxygen levels. Also, Lennon et al. demonstrated that MSCs cultured at 5\% oxygen formed more bone structures in vivo, compared to MSCs grown in $20 \%$ oxygen [105]. Moreover, adipose-derived MSCs grown at low oxygen levels, secreted higher levels of cytokines such as VEGF and FGF compared to cells cultured at $20 \%$ oxygen [102]. Combining the low oxygen condition with growing the MSCs in 3D cultures has been shown to increase the expression of pluripotent genes such as Oct-4, Sox-2, Nanog, and Rex-1 compared to control [99, 106]. Beegle et al. reported that MSCs pretreated with hypoxia before administration enhanced survival rate and cell retention compared to cell grown at $20 \%$ oxygen. Taken together, these studies emphasize the importance of understanding the effects of differences in protocols, culture conditions, and oxygen levels in the context of culturing MSCs 
for clinical trials for COPD where you have gasexchange impairment, active immune response, and inflammation.

\subsubsection{The Exact Mode of Action of MSC In Vivo Needs to Be Discovered}

Despite an enormous interest in using MSCs for clinical settings, the exact in vivo function is not understood, especially not within the lung. A compelling amount of data now points towards that MSCs act by paracrine mechanisms rather than through engraftment [51, 107-116]. Tracking studies of intravenous injected MSCs reveal that most of the injected cells disappear after $24 \mathrm{~h}$ [33, 46, 110, 117], and since MSCs do not engraft it is unlikely that MSCs can remodel injured tissue by differentiating into other cell types. The mechanisms by which MSCs are the most likely to be involved in COPD and emphysema are discussed below.
Immunomodulation through paracrine actions is one of the main mechanisms of actions of MSCs and involves both the innate and the adaptive immune system [118-131] (Fig. 6.2). These effects include inhibition of T-cell [120, 121] and B-cell proliferation [127], macrophage polarization [119], and differentiation of T-cells towards T-regulatory cells [132-134]. The paracrine actions have been associated with several mediators such as hepatocyte growth factor (HGF), transforming growth factor beta (TGF$\beta$ ), prostaglandin (PGE2), IL-10, IFN-gamma, TNF-stimulated gene 6 (TSG6), and indoleamine 2, 3-dioxygenase (IDO) [115, 118, 119, $135,136]$. In addition to the paracrine immunomodulatory effects, MSCs might activate the immune system by recognition of the immune cells. As mentioned, MSCs are rapidly cleared from the lung after infusion, which was recently demonstrated to be mainly through phagocytosis by monocytes [137]. The recognition of MSCs by monocytes results in a polarization of monocytes/macrophages towards an immuno-

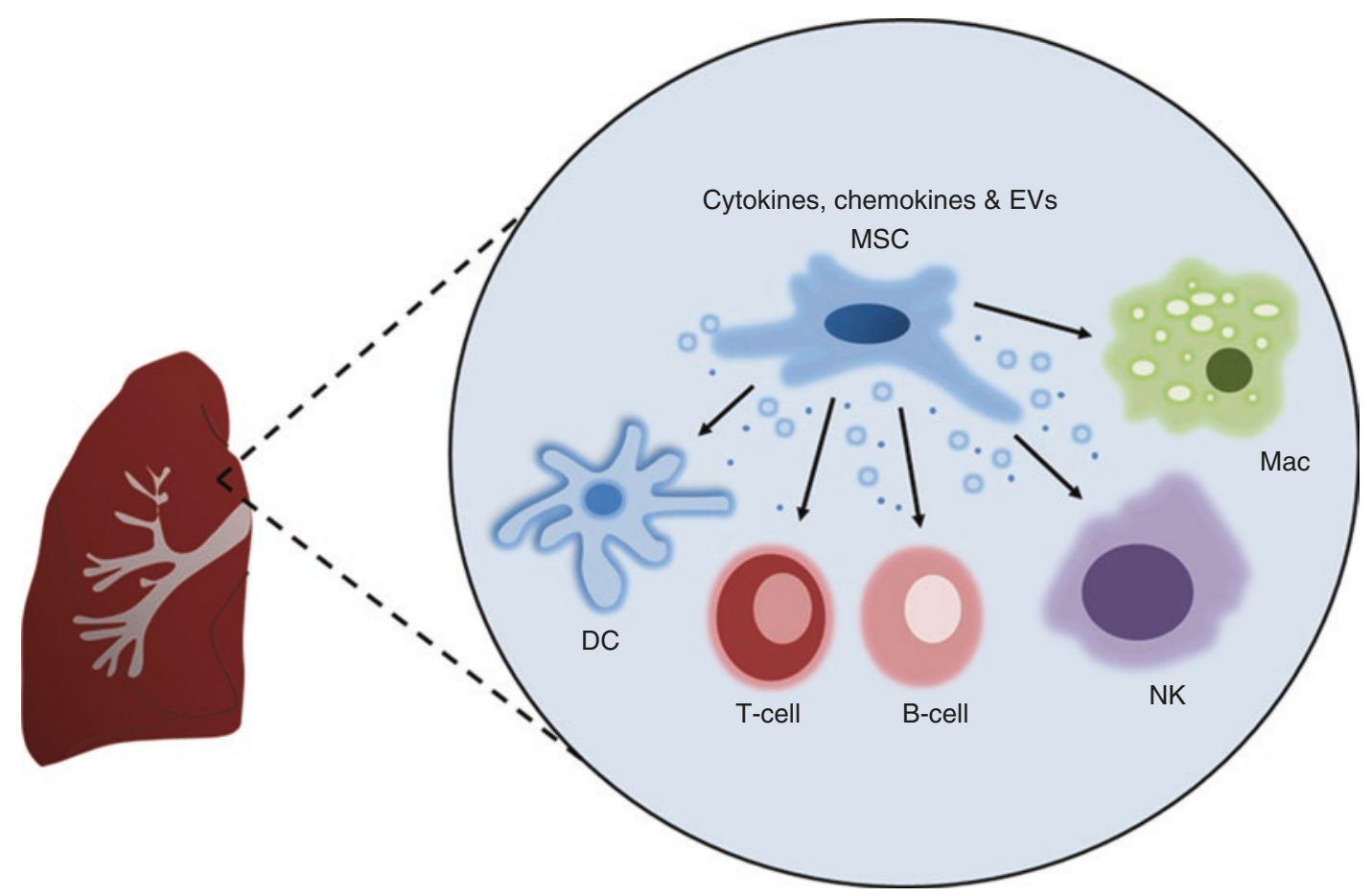

Fig. 6.2 A schematic illustration describing the potential immunomodulatory functions of MSCs. Abbreviations: EVs extracellular vesicles, $M S C s$ mesenchymal stromal cell, $D C$ dendritic cell, $N K$ natural killer cell, Mac macrophage 
suppressive phenotype that results in an immunomodulatory response [137, 138]. Similar results have also been demonstrated with heatinactivated MSCs, suggesting that MSCs also can act in a passive immunomodulatory manner [139]. However the potency of apoptotic MSCs are controversial, apoptotic MSCs have been demonstrated to be completely ineffective when injected intravenously in mice [140]. MSC are also known to secrete antimicrobial proteins and polypeptides that are molecules responsible for bacterial killing. MSCs secrete the antimicrobial peptide, LL-37, following Eschericia coli. stimulation, which was subsequently found to be responsible for the antimicrobial activity in a model of $E$. coli Pneumonia [141]. In addition to its antimicrobial activities, LL-37 can also play an important role in inflammatory and immune modulatory actions [141, 142].

A growing body of data suggests that MSCs can form links with other cells, and that they have the potential to transfer components such as mitochondria [143-146]. Through mitochondrial transfer MSC have been demonstrated to be able to rescue epithelial cells with defective mitochondria [144]. The mitochondria transfer is thought to be via direct transfer by microtubules and tunneling nanotubes (TNT) [144, 147]. MSCs can also transfer mitochondria to macrophages resulting in an increased phagocytic activity [148]. Mitochondrial biogenesis is regulated by extracellular stimuli [149] and several lung diseases are associated with impaired mitochondrial biogenesis and dysfunctional mitochondria [150, 151]. However, beyond the mitochondria-derived reactive oxygen species (ROS), the contribution of mitochondria in the development of COPD is still under investigation [152]. In addition to mitochondria transfer through microtubules and TNT, mitochondria can also be transported via extracellular vesicles (EV) [144, 153-155]. It is also becoming increasingly clear that MSC-derived EVs can influence the behavior of surrounding inflammatory and structural cells. For example, EVs released from MSCs can stimulate bronchial epithelial cells and alveolar cells to secrete proinflammatory cytokines [156, 157]. Furthermore, MSC-derived EVs suppress the potential of lung fibroblasts to differentiate towards myofibroblasts [158]. It is not only mitochondria that could be transferred by MSC-derived EVs, also other components such as microRNA, proteins, lipids, DNA, and mRNA [159, 160]. EVs are taken up by other cells, and EVs derived from MSCs have been demonstrated to impact immune cells. EVs isolated from IL-beta pretreated MSCs induced macrophage polarization towards the anti-inflammatory phenotype (M2) [161]. MSCderived EVs have also been associated with inhibition of T-cell proliferation, inducing apoptosis of activated T-cells and promotion of regulatory T-cells [162]. MSC-derived EVs have been tested in experimental COPD models, but further studies are needed [163].

\subsubsection{The Beneficial Outcome Needs to Be Significantly Increased}

It is now widely accepted that, following in vivo delivery, culture-derived MSCs respond to the microenvironment they encounter, which in COPD and emphysema could encompass everything from massive inflammatory environment to emphysematous tissue destruction. Therefore, it is important to consider several important aspects of the MSC preparation and administration used today.

The route by which MSCs are delivered into the patients most likely plays an important role in the MSC potential function. Despite the fact that several clinical trials has been performed using MSCs for severe lung disorders [29-32, 164-168], the best route of administration have not been determined. In preclinical studies, two main administration routes have been evaluated: systemic administration $[34,41,43,45,47,48$, $50,169,170]$ and local administration [39, 41$43,171,172]$. COPD is a systemic disease and therefore systemic administration might be better suitable for these patients. In addition, systemic administration is less invasive and has less contamination risks compared to local administration [51]. Not only has the route of administration been different in the different studies conducted to date but also the number of cells 
administered with each injection and whether single or multiple injections were administered during the trial. According to Antunes et al. a wide range of MSC doses in preclinical settings have been used, from $10^{4}$ up to $6 \times 10^{6}$ [51]. So far, bone marrow-derived MSCs are the most frequently used cell source for MSC-treatments, especially when used in human clinical trials. However, MSCs derived from other sources such as adipose-derived, umbilical cord-derived, lungderived, and amniotic fluid-derived MSCs have been evaluated for treatment of COPD/emphysema models [36, 41, 50, 172].

Since it is known that the environment affects MSC function and viability, several preconditioning strategies have been tested. Some researchers have been focusing on the effect of the inflammatory environment and the cytokines that may be encountered in the diseased lung [124, 173-179]. Krampera et al. reported that MSCs stimulated with IFN-gamma, increased the levels of IDO produced and secreted by MSCs, leading to an increased suppressive effect on T-lymphocyte proliferation. Moreover, the authors were able to demonstrate that the inhibitory effects of MSCs on T-lymphocyte proliferation were completely abolished when adding an IFN-gamma blocking antibody to the culture system [124]. In an IFNgamma knock out mouse model, Polchert et al. were able to demonstrate that endogenous IFNgamma was required to initiate MSC efficacy. However, after pretreatment of MSCs with high doses of IFN-gamma they immediately became active [173]. Also pre-stimulating MSCs with a combination of inflammatory cytokines has been explored [174, 175]. Another interesting approach to mimic the microenvironment is to utilize patient samples such as serum and bronchoalveolar lavage (BAL) fluid from patients and pre-stimulate cells with such prior to the administration [180, 181]. Moreover, attempts to improve the beneficial effects of MSCs have utilized treatment with the toll-like receptor-3 ligand (poly(I:C)). The authors found that MSCs pretreated with poly(I:C) had improved immunosuppressive properties, an effect that was inhibited by addition of the microRNA miR-143 [182]. In addition to the inflammatory environ- ment, others have studied the effect of pretreating MSCs with hypoxia and nutrient deficiency. During culture under hypoxic conditions, MSCs have been shown to have decreased expression of senescence-associated beta-galactosidase and an increase in the expression of anti-apoptotic proteins such as Bcl-2 and Bcl-xL [183, 184]. By exposing MSCs to hypoxia the hypothesis is that the cells will adapt to the ischemic environment with oxidative stress, an environment they likely will encounter in the COPD lung. This might potentially enhance the time that MSCs can survive and exert their therapeutic paracrine actions in the recipient lung.

A different way of increasing the therapeutic effect by MSCs is to genetically manipulate the cells prior to administration [185-187]. For example, Jiang et al. demonstrated that after co-overexpressing the genes Ang-1 and Akt in MSCs, an increased cell survival and improved angiomyogenesis was observed in an experimental model of acute myocardial infarction [188]. In lung, MSCs overexpressing Ang-1 have been demonstrated to more potently decrease LPSinduced pulmonary inflammation and proinflammatory cytokine release into the BAL fluid [189]. In another study by McGinley et al., overexpression of heat shock protein 27 (HSP27) in MSCs led to decreased apoptosis and improved cardiac function [190]. Overexpression of manganese superoxide dismutase in adipose-derived MSCs, a gene strongly upregulated during hypoxia, increased the time that the MSCs were detectable in a matrigel plug implanted into a mouse model [191]. Moreover, He et al. transduced MSCs with angiotensin-converting enzyme 2 (ACE2), an enzyme that degrades angiotensin II and had previously been demonstrated to have a protective role against acute lung injury. The ACE2transduced MSCs were demonstrated to reduce pulmonary vascular permeability, normalize the expression of eNOS, and improve the endothelial barrier integrity, when infused into an ALI-mouse model. Furthermore, the ACE2 overexpressing MSCs also displayed an improvement in the suppression of the inflammatory response [192].

Combination of different treatments could be another approach to enhance MSC efficacy. 
This approach was used in two of the clinical trials discussed above. Stolk et al. combined MSC treatment with lung volume reduction surgery and de Oliveira et al. with a one-way endobronchial valve insertion [31, 32]. An alternative could be to pretreat the recipient tissue with pharmacological drugs in order to make the recipient site more accessible to the infused cells [104, 193-195]. In a cardiac disease model, pharmacological pretreatment of a vasodilator drug in the recipient site of transplantation resulted in an enhanced delivery of MSCs [193]. In a clinical trial using MSCs for treatment of chronic heart failure, the administration site was treated with a shock wave prior to the administration of the cells. In the group receiving both the shock wave pretreatment and the MSC infusion, the overall occurrence of major adverse cardiac events were significantly decreased compared to the control groups [194].These are all important observations for potential cell-based therapies for lung diseases and should be investigated further.

\subsubsection{Is COPD the Best Disease to Treat with MSC-Based Cell Therapy and How Do We Foresee Which Patients Will Respond to the Treatment?}

The lack of translating the encouraging preclinical data into clinically relevant effects in patients with COPD and emphysema brings up the following question: is COPD the most suitable pulmonary disease for MSC-based treatment? The animal models of COPD and emphysema used in the preclinical studies were optimized to detect the maximum therapeutic effects [196], and might therefore not reflect the in vivo situation that MSCs encounter when infused into patients with COPD and/or emphysema. COPD is characterized by tissue damage, structural changes, and inflammation, and as mentioned it is a heterogeneous disease with different degrees of fibrosis and emphysema [197]. COPD patients with different phenotypes might respond differently to MSC administration
[198], and choosing patients that are more likely to respond to the treatment could be one way to improve the clinical outcome. Another possible way to improve the outcome could be the timing of the treatment. In animal studies, MSCs are frequently administered to the animals in close proximity to the induction of the disease [42, $48,50,172]$ or even at the same time or prior to the disease induction [43, 47]. Based on these preclinical findings, MSCs might be more beneficial earlier in the disease than in later stages of the disease. However, COPD patients tend not to seek medical attention in early stage of the disease [199]. One way to foresee which patients would most likely respond to the treatment could be to develop in vitro potency assays. Even if it is widely accepted that the therapeutic effect of MSCs is mainly mediated by paracrine effects, the exact mechanism of action is not determined. This makes it difficult to develop one single analytic or biological assay, and most likely, a combination of evaluating different mechanisms would be needed [200, 201]. Another potential way would be to develop biomarkers to indicate which patients have an active disease and therefore might benefit more from a MSC-based therapy. To date, several potential biomarkers, including circulating fragments of ECM proteins, have been shown to be increased in COPD patients with an active disease e.g. in relation to acute exacerbations [202-204]. Finally, Broekman et al. suggested that in addition to the optimization of MSC-treatment and potency assays, challenges such as improved outcome parameters needs to be addressed [196].

\subsection{Stem Cell Tourism: A Growing Problem for the Field}

In parallel with the growing interest of cellbased therapies for COPD and other lung diseases, an increased market for commercial stem cell therapies has developed both in the USA and globally [205]. This very unfortunate and problematic outcome might partly be due to an 
increased visibility to desperate patients through the internet and open social media channels [206]. These unproven and often unsafe stem cell treatments can create a situation in which desperate patients easily can be misled into participating in very expensive treatments, which are not covered by insurance. Furthermore, the providers at the stem cell clinics often fail to prove safety and efficacy of their treatments failing to fulfill recognized biological and medical standards, exposing the patients to unnecessary risks and leaving the patient and their family with dashed hopes [205, 207]. These stem cell clinics have the potential to harm even more patients and their families, as well as bring the field into disrepute and hamper the progression of safe and effective MSC-based therapies. Therefore, organizations such as the International Society for Stem Cell Research (ISSCR) and the International Society for Cell and Gene Therapies (ISCT) have taken stances against these unethical cell-therapy clinics. Also, the Food and Drug Administration (FDA) is beginning to take actions against the stem cell tourism [205, 208]. In a review by Dominici et al., the authors discuss the importance of having proper communication between different players such as medical doctors, industry, patient organizations, and patients, in order to enhance credibility and patient welfare [205]. In an attempt to begin proactively addressing this issue, the American Thoracic Society (ATS) Respiratory Cell and Molecular Biology Assembly Stem Cell Working Group posted a statement online and several other related publications [207, 209-212]. This statement will help to translate new scientific findings into patient education in an unbiased way and to make the public aware of the limitations and potential risks associated with such therapeutic approaches [209, 212]. However, it is not only the patients that need education, many pulmonologists are also not familiar with the stem cell field, and the ATS Respiratory Cell and Molecular Biology Assembly Stem Cell Working Group has developed educational resources for this audience also [207].

\subsection{Conclusions}

MSC-based therapy for treatment of COPD and emphysema has demonstrated promising results in animal models; however, this has not translated into clinically relevant effects in patients to date. Current clinical trials have failed to demonstrate efficacy and improved lung function, but importantly they have uniformly demonstrated the MSC administration to be safe. The challenges ahead for this field are to standardize the isolation and culture conditions in order to have a cell product with high quality and reproducibility, to select the proper subpopulation of patients that is most likely to respond to the cell treatment, to develop appropriate potency assays, and to improve or develop new methods to measure outcomes. Furthermore, the usage of cell-free products such as EVs and conditioned medium, or pretreating MSCs prior to administration has demonstrated promising results. However, there is still a long way to go and many challenges are ahead before we have an optimal MSC-based treatment for patients with COPD and emphysema.

\section{References}

1. Mahboub BH, Vats MG, Al Zaabi A, Iqbal MN, Safwat $\mathrm{T}$, Al-Hurish F, et al. Joint statement for the diagnosis, management, and prevention of chronic obstructive pulmonary disease for gulf cooperation council countries and Middle East-North Africa region, 2017. Int J Chron Obstruct Pulmon Dis. 2017;12:2869-90.

2. Organization WH. Chronic obstructive pulmonary disease (COPD) fact sheet. WHO. 2016.

3. Mathers CD, Loncar D. Projections of global mortality and burden of disease from 2002 to 2030. PLoS Med. 2006;3(11):e442.

4. Hess MW. The 2017 global initiative for chronic obstructive lung disease report and practice implications for the respiratory therapist. Respir Care. 2017;62(11):1492-500.

5. Savukinas UB, Enes SR, Sjoland AA, WestergrenThorsson G. Concise review: the bystander effect: mesenchymal stem cell-mediated lung repair. Stem Cells. 2016;34(6):1437-44.

6. Keating A. Mesenchymal stromal cells: new directions. Cell Stem Cell. 2012;10(6):709-16. 
7. Kaiser LR. The future of multihospital systems. Top Health Care Financ. 1992;18(4):32-45.

8. Lokke A, Lange P, Scharling H, Fabricius P, Vestbo J. Developing COPD: a 25 year follow up study of the general population. Thorax. 2006;61(11):935-9.

9. Rennard SI, Vestbo J. COPD: the dangerous underestimate of 15\%. Lancet. 2006;367(9518):1216-9.

10. Lamprecht B, Soriano JB, Studnicka M, Kaiser B, Vanfleteren LE, Gnatiuc L, et al. Determinants of underdiagnosis of COPD in national and international surveys. Chest. 2015;148(4):971-85.

11. Negewo NA, Gibson PG, McDonald VM. COPD and its comorbidities: impact, measurement and mechanisms. Respirology. 2015;20(8):1160-71.

12. Barrecheguren M, Miravitlles M. COPD heterogeneity: implications for management. Multidiscip Respir Med. 2016;11:14.

13. Petty TL. The history of COPD. Int J Chron Obstruct Pulmon Dis. 2006;1(1):3-14.

14. Enslein K. The natural history of chronic bronchitis and emphysema: an eight year study of early chronic obstructive lung disease in working men in London. Technometrics. 1978;20(2):212-3.

15. Celli B, ZuWallack R, Wang S, Kesten S. Improvement in resting inspiratory capacity and hyperinflation with tiotropium in COPD patients with increased static lung volumes. Chest. 2003;124(5):1743-8.

16. Barnes PJ. How corticosteroids control inflammation: quintiles prize lecture 2005. Br J Pharmacol. 2006;148(3):245-54.

17. Hogg JC, Timens W. The pathology of chronic obstructive pulmonary disease. Annu Rev Pathol. 2009;4:435-59.

18. Woodruff PG, Koth LL, Yang YH, Rodriguez MW, Favoreto S, Dolganov GM, et al. A distinctive alveolar macrophage activation state induced by cigarette smoking. Am J Respir Crit Care Med. 2005;172(11):1383-92.

19. Lambrecht BN. Alveolar macrophage in the driver's seat. Immunity. 2006;24(4):366-8.

20. Meyers BF, Patterson GA. Chronic obstructive pulmonary disease 10: bullectomy, lung volume reduction surgery, and transplantation for patients with chronic obstructive pulmonary disease. Thorax. 2003;58(7):634-8.

21. Berger RL, Decamp MM, Criner GJ, Celli BR. Lung volume reduction therapies for advanced emphysema: an update. Chest. 2010;138(2):407-17.

22. Meyers BF. Complications of lung volume reduction surgery. Semin Thorac Cardiovasc Surg. 2002; 14(4):399-402.

23. Criner GJ, Pinto-Plata V, Strange C, Dransfield M, Gotfried M, Leeds W, et al. Biologic lung volume reduction in advanced upper lobe emphysema: phase 2 results. Am J Respir Crit Care Med. 2009;179(9):791-8.

24. Taraseviciene-Stewart L, Voelkel NF. Molecular pathogenesis of emphysema. $\mathrm{J}$ Clin Invest. 2008;118(2):394-402.
25. Verleden GM, Raghu G, Meyer KC, Glanville AR, Corris P. A new classification system for chronic lung allograft dysfunction. J Heart Lung Transplant. 2014;33(2):127-33.

26. Estenne M, Hertz MI. Bronchiolitis obliterans after human lung transplantation. Am J Respir Crit Care Med. 2002;166(4):440-4.

27. Boehler A, Kesten S, Weder W, Speich R. Bronchiolitis obliterans after lung transplantation: a review. Chest. 1998;114(5):1411-26.

28. ClinicalTrials.gov [Internet] 2018. [cited 2018-11-28].

29. Ribeiro-Paes JT, Bilaqui A, Greco OT, Ruiz MA, Marcelino MY, Stessuk T, et al. Unicentric study of cell therapy in chronic obstructive pulmonary disease/ pulmonary emphysema. Int J Chron Obstruct Pulmon Dis. 2011;6:63-71.

30. Weiss DJ, Casaburi R, Flannery R, LeRoux-Williams M, Tashkin DP. A placebo-controlled, randomized trial of mesenchymal stem cells in COPD. Chest. 2013;143(6):1590-8.

31. Stolk J, Broekman W, Mauad T, Zwaginga JJ, Roelofs $\mathrm{H}$, Fibbe WE, et al. A phase I study for intravenous autologous mesenchymal stromal cell administration to patients with severe emphysema. QJM. 2016;109(5):331-6.

32. de Oliveira HG, Cruz FF, Antunes MA, de Macedo Neto AV, Oliveira GA, Svartman FM, et al. Combined bone marrow-derived mesenchymal stromal cell therapy and one-way endobronchial valve placement in patients with pulmonary emphysema: a phase I clinical trial. Stem Cells Transl Med. 2017;6(3):962-9.

33. Armitage J, Tan DBA, Troedson R, Young P, Lam $\mathrm{KV}$, Shaw K, et al. Mesenchymal stromal cell infusion modulates systemic immunological responses in stable COPD patients: a phase I pilot study. Eur Respir J. 2018;51(3).

34. Huh JW, Kim SY, Lee JH, Lee JS, Van Ta Q, Kim $\mathrm{M}$, et al. Bone marrow cells repair cigarette smokeinduced emphysema in rats. Am J Physiol Lung Cell Mol Physiol. 2011;301(3):L255-66.

35. Kim SY, Lee JH, Kim HJ, Park MK, Huh JW, Ro JY, et al. Mesenchymal stem cell-conditioned media recovers lung fibroblasts from cigarette smokeinduced damage. Am J Physiol Lung Cell Mol Physiol. 2012;302(9):L891-908.

36. Schweitzer KS, Johnstone BH, Garrison J, Rush NI, Cooper S, Traktuev DO, et al. Adipose stem cell treatment in mice attenuates lung and systemic injury induced by cigarette smoking. Am J Respir Crit Care Med. 2011;183(2):215-25.

37. Hoffman AM, Paxson JA, Mazan MR, Davis AM, Tyagi S, Murthy S, et al. Lung-derived mesenchymal stromal cell post-transplantation survival, persistence, paracrine expression, and repair of elastase-injured lung. Stem Cells Dev. 2011;20(10):1779-92.

38. Ingenito EP, Tsai L, Murthy S, Tyagi S, Mazan M, Hoffman A. Autologous lung-derived mesenchymal stem cell transplantation in experimental emphysema. Cell Transplant. 2012;21(1):175-89. 
39. Gu W, Song L, Li XM, Wang D, Guo XJ, Xu WG. Mesenchymal stem cells alleviate airway inflammation and emphysema in COPD through down-regulation of cyclooxygenase-2 via p38 and ERK MAPK pathways. Sci Rep. 2015;5:8733.

40. Longhini-Dos-Santos N, Barbosa-de-Oliveira VA, Kozma RH, Faria CA, Stessuk T, Frei F, et al. Cell therapy with bone marrow mononuclear cells in elastase-induced pulmonary emphysema. Stem Cell Rev. 2013;9(2):210-8.

41. Antunes MA, Abreu SC, Cruz FF, Teixeira AC, Lopes-Pacheco M, Bandeira E, et al. Effects of different mesenchymal stromal cell sources and delivery routes in experimental emphysema. Respir Res. 2014;15:118.

42. Katsha AM, Ohkouchi S, Xin H, Kanehira M, Sun R, Nukiwa T, et al. Paracrine factors of multipotent stromal cells ameliorate lung injury in an elastase-induced emphysema model. Mol Ther. 2011;19(1):196-203.

43. Tibboel J, Keijzer R, Reiss I, de Jongste JC, Post $\mathrm{M}$. Intravenous and intratracheal mesenchymal stromal cell injection in a mouse model of pulmonary emphysema. COPD. 2014;11(3):310-8.

44. Chen YB, Lan YW, Chen LG, Huang TT, Choo KB, Cheng WT, et al. Mesenchymal stem cell-based HSP70 promoter-driven VEGFA induction by resveratrol alleviates elastase-induced emphysema in a mouse model. Cell Stress Chaperones. 2015;20(6):979-89.

45. Kim YS, Kim JY, Huh JW, Lee SW, Choi SJ, Oh YM. The therapeutic effects of optimal dose of mesenchymal stem cells in a murine model of an elastase induced-emphysema. Tuberc Respir Dis (Seoul). 2015;78(3):239-45.

46. Kim YS, Kim JY, Shin DM, Huh JW, Lee SW, Oh YM. Tracking intravenous adipose-derived mesenchymal stem cells in a model of elastase-induced emphysema. Tuberc Respir Dis (Seoul). 2014;77(3):116-23.

47. Zhen G, Liu H, Gu N, Zhang H, Xu Y, Zhang Z. Mesenchymal stem cells transplantation protects against rat pulmonary emphysema. Front Biosci. 2008;13:3415-22.

48. Zhen G, Xue Z, Zhao J, Gu N, Tang Z, Xu Y, et al. Mesenchymal stem cell transplantation increases expression of vascular endothelial growth factor in papain-induced emphysematous lungs and inhibits apoptosis of lung cells. Cytotherapy. 2010;12(5):605-14.

49. Shigemura N, Okumura M, Mizuno S, Imanishi Y, Matsuyama A, Shiono H, et al. Lung tissue engineering technique with adipose stromal cells improves surgical outcome for pulmonary emphysema. Am J Respir Crit Care Med. 2006;174(11):1199-205.

50. Shigemura N, Okumura M, Mizuno S, Imanishi Y, Nakamura T, Sawa Y. Autologous transplantation of adipose tissue-derived stromal cells ameliorates pulmonary emphysema. Am J Transplant. 2006;6(11):2592-600.

51. Antunes MA, Lapa ESJR, Rocco PR. Mesenchymal stromal cell therapy in COPD: from bench to bedside. Int J Chron Obstruct Pulmon Dis. 2017;12:3017-27.
52. Anjos-Afonso F, Bonnet D. Flexible and dynamic organization of bone marrow stromal compartment. Br J Haematol. 2007;139(3):373-84.

53. Bianco P, Riminucci M, Gronthos S, Robey PG. Bone marrow stromal stem cells: nature, biology, and potential applications. Stem Cells. 2001;19(3):180-92.

54. Battula VL, Treml S, Bareiss PM, Gieseke F, Roelofs $\mathrm{H}$, de Zwart $\mathrm{P}$, et al. Isolation of functionally distinct mesenchymal stem cell subsets using antibodies against CD56, CD271, and mesenchymal stem cell antigen-1. Haematologica. 2009;94(2):173-84.

55. Tormin A, Brune JC, Olsson E, Valcich J, Neuman U, Olofsson $\mathrm{T}$, et al. Characterization of bone marrowderived mesenchymal stromal cells (MSC) based on gene expression profiling of functionally defined MSC subsets. Cytotherapy. 2009;11(2):114-28.

56. Martin I, De Boer J, Sensebe L, Therapy MSCCotISfC. A relativity concept in mesenchymal stromal cell manufacturing. Cytotherapy. 2016;18(5):613-20.

57. Rolandsson Enes S, Ahrman E, Palani A, Hallgren O, Bjermer L, Malmstrom A, et al. Quantitative proteomic characterization of lung-MSC and bone marrow-MSC using DIA-mass spectrometry. Sci Rep. 2017;7(1):9316.

58. Rolandsson Enes S, Andersson Sjoland A, Skog I, Hansson L, Larsson H, Le Blanc K, et al. MSC from fetal and adult lungs possess lung-specific properties compared to bone marrow-derived MSC. Sci Rep. 2016;6:29160.

59. Rolandsson S, Andersson Sjoland A, Brune JC, Li H, Kassem M, Mertens F, et al. Primary mesenchymal stem cells in human transplanted lungs are CD90/ CD105 perivascularly located tissue-resident cells. BMJ Open Respir Res. 2014;1(1):e000027.

60. Dominici M, Le Blanc K, Mueller I, SlaperCortenbach I, Marini F, Krause D, et al. Minimal criteria for defining multipotent mesenchymal stromal cells. The International Society for Cellular Therapy position statement. Cytotherapy. 2006;8(4):315-7.

61. Troyer DL, Weiss ML. Wharton's jelly-derived cells are a primitive stromal cell population. Stem Cells. 2008;26(3):591-9.

62. Ding DC, Chang YH, Shyu WC, Lin SZ. Human umbilical cord mesenchymal stem cells: a new era for stem cell therapy. Cell Transplant. 2015;24(3):339-47.

63. Zuk PA, Zhu M, Mizuno H, Huang J, Futrell JW, Katz AJ, et al. Multilineage cells from human adipose tissue: implications for cell-based therapies. Tissue Eng. 2001;7(2):211-28.

64. Mahmoudifar N, Doran PM. Mesenchymal stem cells derived from human adipose tissue. Methods Mol Biol. 2015;1340:53-64.

65. in't Anker PS, Noort WA, Scherjon SA, Kleijburgvan der Keur C, Kruisselbrink AB, van Bezooijen $\mathrm{RL}$, et al. Mesenchymal stem cells in human secondtrimester bone marrow, liver, lung, and spleen exhibit a similar immunophenotype but a heterogeneous multilineage differentiation potential. Haematologica. 2003;88(8):845-52. 
66. Lama VN, Smith L, Badri L, Flint A, Andrei AC, Murray S, et al. Evidence for tissue-resident mesenchymal stem cells in human adult lung from studies of transplanted allografts. J Clin Invest. 2007;117(4):989-96.

67. Pires AO, Mendes-Pinheiro B, Teixeira FG, Anjo SI, Ribeiro-Samy S, Gomes ED, et al. Unveiling the differences of secretome of human bone marrow mesenchymal stem cells, adipose tissue-derived stem cells, and human umbilical cord perivascular cells: a proteomic analysis. Stem Cells Dev. 2016;25(14):1073-83.

68. Li H, Ghazanfari R, Zacharaki D, Ditzel N, Isern J, Ekblom M, et al. Low/negative expression of PDGFRalpha identifies the candidate primary mesenchymal stromal cells in adult human bone marrow. Stem Cell Reports. 2014;3(6):965-74.

69. Wagner W, Ho AD, Zenke M. Different facets of aging in human mesenchymal stem cells. Tissue Eng Part B Rev. 2010;16(4):445-53.

70. Siddappa R, Licht R, van Blitterswijk C, de Boer J. Donor variation and loss of multipotency during in vitro expansion of human mesenchymal stem cells for bone tissue engineering. J Orthop Res. 2007;25(8):1029-41.

71. Estrada JC, Torres Y, Benguria A, Dopazo A, Roche E, Carrera-Quintanar L, et al. Human mesenchymal stem cell-replicative senescence and oxidative stress are closely linked to aneuploidy. Cell Death Dis. 2013;4:e691.

72. Redaelli S, Bentivegna A, Foudah D, Miloso M, Redondo J, Riva G, et al. From cytogenomic to epigenomic profiles: monitoring the biologic behavior of in vitro cultured human bone marrow mesenchymal stem cells. Stem Cell Res Ther. 2012;3(6):47.

73. Alves H, Munoz-Najar U, De Wit J, Renard AJ, Hoeijmakers JH, Sedivy JM, et al. A link between the accumulation of DNA damage and loss of multipotency of human mesenchymal stromal cells. J Cell Mol Med. 2010;14(12):2729-38.

74. Schubert S, Brehm W, Hillmann A, Burk J. Serumfree human MSC medium supports consistency in human but not in equine adipose-derived multipotent mesenchymal stromal cell culture. Cytometry A. 2018;93(1):60-72.

75. Ren J, Ward D, Chen S, Tran K, Jin P, Sabatino M, et al. Comparison of human bone marrow stromal cells cultured in human platelet growth factors and fetal bovine serum. J Transl Med. 2018;16(1):65.

76. Horn P, Bokermann G, Cholewa D, Bork S, Walenda $\mathrm{T}$, Koch C, et al. Impact of individual platelet lysates on isolation and growth of human mesenchymal stromal cells. Cytotherapy. 2010;12(7):888-98.

77. Lensch M, Muise A, White L, Badowski M, Harris D. Comparison of synthetic media designed for expansion of adipose-derived mesenchymal stromal cells. Biomedicines. 2018;6(2):pii: E54.

78. Francois M, Copland IB, Yuan S, Romieu-Mourez R, Waller EK, Galipeau J. Cryopreserved mesenchymal stromal cells display impaired immunosuppres- sive properties as a result of heat-shock response and impaired interferon-gamma licensing. Cytotherapy. 2012;14(2):147-52.

79. Moll G, Alm JJ, Davies LC, von Bahr L, Heldring $\mathrm{N}$, Stenbeck-Funke L, et al. Do cryopreserved mesenchymal stromal cells display impaired immunomodulatory and therapeutic properties? Stem Cells. 2014;32(9):2430-42.

80. Hoogduijn MJ, de Witte SF, Luk F, van den Hout-van Vroonhoven MC, Ignatowicz L, Catar R, et al. Effects of freeze-thawing and intravenous infusion on mesenchymal stromal cell gene expression. Stem Cells Dev. 2016;25(8):586-97.

81. Cruz FF, Borg ZD, Goodwin M, Sokocevic D, Wagner D, McKenna DH, et al. Freshly thawed and continuously cultured human bone marrow-derived mesenchymal stromal cells comparably ameliorate allergic airways inflammation in immunocompetent mice. Stem Cells Transl Med. 2015;4(6):615-24.

82. Salzig D, Leber J, Merkewitz K, Lange MC, Koster N, Czermak P. Attachment, growth, and detachment of human mesenchymal stem cells in a chemically defined medium. Stem Cells Int. 2016;2016:5246584.

83. Somaiah C, Kumar A, Mawrie D, Sharma A, Patil $\mathrm{SD}$, Bhattacharyya J, et al. Collagen promotes higher adhesion, survival and proliferation of mesenchymal stem cells. PLoS One. 2015;10(12):e0145068.

84. Burgess JK, Mauad T, Tjin G, Karlsson JC, Westergren-Thorsson G. The extracellular matrix the under-recognized element in lung disease? J Pathol. 2016;240(4):397-409.

85. Engler AJ, Sen S, Sweeney HL, Discher DE. Matrix elasticity directs stem cell lineage specification. Cell. 2006;126(4):677-89.

86. Trappmann B, Gautrot JE, Connelly JT, Strange DG, Li Y, Oyen ML, et al. Extracellular-matrix tethering regulates stem-cell fate. Nat Mater. 2012;11(7):642-9.

87. Kilian KA, Bugarija B, Lahn BT, Mrksich M. Geometric cues for directing the differentiation of mesenchymal stem cells. Proc Natl Acad Sci U S A. 2010;107(11):4872-7.

88. McBeath R, Pirone DM, Nelson CM, Bhadriraju K, Chen CS. Cell shape, cytoskeletal tension, and RhoA regulate stem cell lineage commitment. Dev Cell. 2004;6(4):483-95.

89. McMurray RJ, Gadegaard N, Tsimbouri PM, Burgess $\mathrm{KV}$, McNamara LE, Tare R, et al. Nanoscale surfaces for the long-term maintenance of mesenchymal stem cell phenotype and multipotency. Nat Mater. 2011;10(8):637-44.

90. Schmal O, Seifert J, Schaffer TE, Walter CB, Aicher WK, Klein G. Hematopoietic stem and progenitor cell expansion in contact with mesenchymal stromal cells in a hanging drop model uncovers disadvantages of 3D culture. Stem Cells Int. 2016;2016:4148093.

91. Bae YJ, Kwon YR, Kim HJ, Lee S, Kim YJ. Enhanced differentiation of mesenchymal stromal cells by three-dimensional culture and azacitidine. Blood Res. 2017;52(1):18-24. 
92. Uhl FE, Wagner DE, Weiss DJ. Preparation of decellularized lung matrices for cell culture and protein analysis. Methods Mol Biol. 2017;1627:253-83.

93. Zvarova B, Uhl FE, Uriarte JJ, Borg ZD, Coffey AL, Bonenfant NR, et al. Residual detergent detection method for nondestructive cytocompatibility evaluation of decellularized whole lung scaffolds. Tissue Eng Part C Methods. 2016;22(5):418-28.

94. Mebarki M, Coquelin L, Layrolle P, Battaglia S, Tossou M, Hernigou P, et al. Enhanced human bone marrow mesenchymal stromal cell adhesion on scaffolds promotes cell survival and bone formation. Acta Biomater. 2017;59:94-107.

95. Link PA, Pouliot RA, Mikhaiel NS, Young BM, Heise RL. Tunable hydrogels from pulmonary extracellular matrix for 3D cell culture. J Vis Exp. 2017;(119):1-9.

96. Redondo-Castro E, Cunningham CJ, Miller J, Brown H, Allan SM, Pinteaux E. Changes in the secretome of tri-dimensional spheroid-cultured human mesenchymal stem cells in vitro by interleukin-1 priming. Stem Cell Res Ther. 2018;9(1):11.

97. Kim S, Han YS, Lee JH, Lee SH. Combination of MSC spheroids wrapped within autologous composite sheet dually protects against immune rejection and enhances stem cell transplantation efficacy. Tissue Cell. 2018;53:93-103.

98. Choi JR, Pingguan-Murphy B, Wan Abas WA, Yong KW, Poon CT, Noor Azmi MA, et al. In situ normoxia enhances survival and proliferation rate of human adipose tissue-derived stromal cells without increasing the risk of tumourigenesis. PLoS One. 2015;10(1):e0115034.

99. Choi JR, Pingguan-Murphy B, Wan Abas WA, Noor Azmi MA, Omar SZ, Chua KH, et al. Impact of low oxygen tension on stemness, proliferation and differentiation potential of human adiposederived stem cells. Biochem Biophys Res Commun. 2014;448(2):218-24.

100. Cooper PD, Burt AM, Wilson JN. Critical effect of oxygen tension on rate of growth of animal cells in continuous suspended culture. Nature. 1958;182(4648):1508-9.

101. Ivanovic Z, Dello Sbarba P, Trimoreau F, Faucher JL, Praloran V. Primitive human HPCs are better maintained and expanded in vitro at 1 percent oxygen than at 20 percent. Transfusion. 2000;40(12):1482-8.

102. Choi JR, Yong KW, Wan Safwani WKZ. Effect of hypoxia on human adipose-derived mesenchymal stem cells and its potential clinical applications. Cell Mol Life Sci. 2017;74(14):2587-600.

103. Taylor CT, Colgan SP. Regulation of immunity and inflammation by hypoxia in immunological niches. Nat Rev Immunol. 2017;17(12):774-85.

104. Baldari S, Di Rocco G, Piccoli M, Pozzobon M, Muraca M, Toietta G. Challenges and strategies for improving the regenerative effects of mesenchymal stromal cell-based therapies. Int J Mol Sci. 2017;18(10).
105. Lennon DP, Edmison JM, Caplan AI. Cultivation of rat marrow-derived mesenchymal stem cells in reduced oxygen tension: effects on in vitro and in vivo osteochondrogenesis. J Cell Physiol. 2001;187(3):345-55.

106. Grayson WL, Zhao F, Izadpanah R, Bunnell B, Ma T. Effects of hypoxia on human mesenchymal stem cell expansion and plasticity in 3D constructs. J Cell Physiol. 2006;207(2):331-9.

107. Weiss DJ. Concise review: current status of stem cells and regenerative medicine in lung biology and diseases. Stem Cells. 2014;32(1):16-25.

108. Cilloni D, Carlo-Stella C, Falzetti F, Sammarelli G, Regazzi E, Colla S, et al. Limited engraftment capacity of bone marrow-derived mesenchymal cells following T-cell-depleted hematopoietic stem cell transplantation. Blood. 2000;96(10):3637-43.

109. Wang Y, Chen X, Cao W, Shi Y. Plasticity of mesenchymal stem cells in immunomodulation: pathological and therapeutic implications. Nat Immunol. 2014;15(11):1009-16.

110. von Bahr L, Batsis I, Moll G, Hagg M, Szakos A, Sundberg B, et al. Analysis of tissues following mesenchymal stromal cell therapy in humans indicates limited long-term engraftment and no ectopic tissue formation. Stem Cells. 2012;30(7):1575-8.

111. Togel $\mathrm{F}, \mathrm{Hu} \mathrm{Z}$, Weiss $\mathrm{K}$, Isaac $\mathrm{J}$, Lange $\mathrm{C}$, Westenfelder C. Administered mesenchymal stem cells protect against ischemic acute renal failure through differentiation-independent mechanisms. Am J Physiol Renal Physiol. 2005;289(1):F31-42.

112. Prockop DJ, Kota DJ, Bazhanov N, Reger RL. Evolving paradigms for repair of tissues by adult stem/progenitor cells (MSCs). J Cell Mol Med. 2010;14(9):2190-9.

113. Lee RH, Pulin AA, Seo MJ, Kota DJ, Ylostalo J, Larson BL, et al. Intravenous hMSCs improve myocardial infarction in mice because cells embolized in lung are activated to secrete the anti-inflammatory protein TSG-6. Cell Stem Cell. 2009;5(1):54-63.

114. Bai L, Lennon DP, Caplan AI, DeChant A, Hecker J, Kranso J, et al. Hepatocyte growth factor mediates mesenchymal stem cell-induced recovery in multiple sclerosis models. Nat Neurosci. 2012;15(6):862-70.

115. Bernardo ME, Fibbe WE. Mesenchymal stromal cells: sensors and switchers of inflammation. Cell Stem Cell. 2013;13(4):392-402.

116. dos Santos CC, Murthy S, Hu P, Shan Y, Haitsma JJ, Mei SH, et al. Network analysis of transcriptional responses induced by mesenchymal stem cell treatment of experimental sepsis. Am J Pathol. 2012;181(5):1681-92.

117. Xu J, Woods CR, Mora AL, Joodi R, Brigham KL, Iyer $\mathrm{S}$, et al. Prevention of endotoxin-induced systemic response by bone marrow-derived mesenchymal stem cells in mice. Am J Physiol Lung Cell Mol Physiol. 2007;293(1):L131-41.

118. Le Blanc K, Mougiakakos D. Multipotent mesenchymal stromal cells and the innate immune system. Nat Rev Immunol. 2012;12(5):383-96. 
119. Bernardo ME, Fibbe WE. Mesenchymal stromal cells and hematopoietic stem cell transplantation. Immunol Lett. 2015;168(2):215-21.

120. Di Nicola M, Carlo-Stella C, Magni M, Milanesi M, Longoni PD, Matteucci P, et al. Human bone marrow stromal cells suppress T-lymphocyte proliferation induced by cellular or nonspecific mitogenic stimuli. Blood. 2002;99(10):3838-43.

121. Le Blanc K, Tammik L, Sundberg B, Haynesworth SE, Ringden O. Mesenchymal stem cells inhibit and stimulate mixed lymphocyte cultures and mitogenic responses independently of the major histocompatibility complex. Scand J Immunol. 2003;57(1):11-20.

122. Krampera M, Glennie S, Dyson J, Scott D, Laylor R, Simpson E, et al. Bone marrow mesenchymal stem cells inhibit the response of naive and memory antigen-specific $\mathrm{T}$ cells to their cognate peptide. Blood. 2003;101(9):3722-9.

123. Glennie S, Soeiro I, Dyson PJ, Lam EW, Dazzi F. Bone marrow mesenchymal stem cells induce division arrest anergy of activated $\mathrm{T}$ cells. Blood. 2005;105(7):2821-7.

124. Krampera M, Cosmi L, Angeli R, Pasini A, Liotta $\mathrm{F}$, Andreini A, et al. Role for interferon-gamma in the immunomodulatory activity of human bone marrow mesenchymal stem cells. Stem Cells. 2006;24(2):386-98.

125. Ghannam S, Pene J, Moquet-Torcy G, Jorgensen C, Yssel H. Mesenchymal stem cells inhibit human Th17 cell differentiation and function and induce a $\mathrm{T}$ regulatory cell phenotype. J Immunol. 2010;185(1):302-12.

126. Prigione I, Benvenuto F, Bocca P, Battistini L, Uccelli A, Pistoia V. Reciprocal interactions between human mesenchymal stem cells and gammadelta $\mathrm{T}$ cells or invariant natural killer T cells. Stem Cells. 2009;27(3):693-702.

127. Corcione A, Benvenuto F, Ferretti E, Giunti D, Cappiello V, Cazzanti F, et al. Human mesenchymal stem cells modulate B-cell functions. Blood. 2006;107(1):367-72.

128. Spaggiari GM, Capobianco A, Becchetti S, Mingari MC, Moretta L. Mesenchymal stem cell-natural killer cell interactions: evidence that activated NK cells are capable of killing MSCs, whereas MSCs can inhibit IL-2-induced NK-cell proliferation. Blood. 2006;107(4):1484-90.

129. Ramasamy R, Fazekasova H, Lam EW, Soeiro I, Lombardi G, Dazzi F. Mesenchymal stem cells inhibit dendritic cell differentiation and function by preventing entry into the cell cycle. Transplantation. 2007;83(1):71-6.

130. Raffaghello L, Bianchi G, Bertolotto M, Montecucco F, Busca A, Dallegri F, et al. Human mesenchymal stem cells inhibit neutrophil apoptosis: a model for neutrophil preservation in the bone marrow niche. Stem Cells. 2008;26(1):151-62.

131. Waterman RS, Tomchuck SL, Henkle SL, Betancourt AM. A new mesenchymal stem cell (MSC) paradigm: polarization into a pro-inflammatory MSC1 or an immunosuppressive MSC2 phenotype. PLoS One. 2010;5(4):e10088.

132. Akiyama K, Chen C, Wang D, Xu X, Qu C, Yamaza $\mathrm{T}$, et al. Mesenchymal-stem-cell-induced immunoregulation involves FAS-ligand-/FAS-mediated T cell apoptosis. Cell Stem Cell. 2012;10(5):544-55.

133. Maccario R, Podesta M, Moretta A, Cometa A, Comoli P, Montagna D, et al. Interaction of human mesenchymal stem cells with cells involved in alloantigen-specific immune response favors the differentiation of CD4+ T-cell subsets expressing a regulatory/suppressive phenotype. Haematologica. 2005;90(4):516-25.

134. English K, Ryan JM, Tobin L, Murphy MJ, Barry FP, Mahon BP. Cell contact, prostaglandin E(2) and transforming growth factor beta 1 play non-redundant roles in human mesenchymal stem cell induction of CD4+CD25(high) forkhead box P3+ regulatory $\mathrm{T}$ cells. Clin Exp Immunol. 2009;156(1):149-60.

135. Nemeth K, Leelahavanichkul A, Yuen PS, Mayer B, Parmelee A, Doi K, et al. Bone marrow stromal cells attenuate sepsis via prostaglandin E(2)dependent reprogramming of host macrophages to increase their interleukin-10 production. Nat Med. 2009;15(1):42-9.

136. Choi H, Lee RH, Bazhanov N, Oh JY, Prockop DJ. Anti-inflammatory protein TSG-6 secreted by activated MSCs attenuates zymosan-induced mouse peritonitis by decreasing TLR2/NF-kappaB signaling in resident macrophages. Blood. 2011;118(2):330-8.

137. de Witte SFH, Luk F, Sierra Parraga JM, Gargesha M, Merino A, Korevaar SS, et al. Immunomodulation by therapeutic mesenchymal stromal cells (MSC) is triggered through phagocytosis of MSC by monocytic cells. Stem Cells. 2018;36(4):602-15.

138. Braza F, Dirou S, Forest V, Sauzeau V, Hassoun $\mathrm{D}$, Chesne J, et al. Mesenchymal stem cells induce suppressive macrophages through phagocytosis in a mouse model of asthma. Stem Cells. 2016;34(7):1836-45.

139. Luk F, de Witte SF, Korevaar SS, Roemeling-van Rhijn M, Franquesa M, Strini T, et al. Inactivated mesenchymal stem cells maintain immunomodulatory capacity. Stem Cells Dev. 2016;25(18):1342-54.

140. Galipeau J, Sensebe L. Mesenchymal stromal cells: clinical challenges and therapeutic opportunities. Cell Stem Cell. 2018;22(6):824-33.

141. Krasnodembskaya A, Song Y, Fang X, Gupta N, Serikov V, Lee JW, et al. Antibacterial effect of human mesenchymal stem cells is mediated in part from secretion of the antimicrobial peptide LL-37. Stem Cells. 2010;28(12):2229-38.

142. Hu Z, Murakami T, Suzuki K, Tamura H, KuwaharaArai K, Iba T, et al. Antimicrobial cathelicidin peptide LL-37 inhibits the LPS/ATP-induced pyroptosis of macrophages by dual mechanism. PLoS One. 2014;9(1):e85765.

143. Weiss DJ. Stem cells, cell therapies, and bioengineering in lung biology and diseases. Comprehensive 
review of the recent literature 2010-2012. Ann Am Thorac Soc. 2013;10(5):S45-97.

144. Spees JL, Olson SD, Whitney MJ, Prockop DJ. Mitochondrial transfer between cells can rescue aerobic respiration. Proc Natl Acad Sci U S A. 2006;103(5):1283-8.

145. Plotnikov EY, Khryapenkova TG, Vasileva AK, Marey MV, Galkina SI, Isaev NK, et al. Cell-tocell cross-talk between mesenchymal stem cells and cardiomyocytes in co-culture. J Cell Mol Med. 2008;12(5A):1622-31.

146. Spees JL, Lee RH, Gregory CA. Mechanisms of mesenchymal stem/stromal cell function. Stem Cell Res Ther. 2016;7(1):125.

147. Sinclair KA, Yerkovich ST, Hopkins PM, Chambers DC. Characterization of intercellular communication and mitochondrial donation by mesenchymal stromal cells derived from the human lung. Stem Cell Res Ther. 2016;7(1):91.

148. Jackson MV, Morrison TJ, Doherty DF, McAuley DF, Matthay MA, Kissenpfennig A, et al. Mitochondrial transfer via tunneling nanotubes is an important mechanism by which mesenchymal stem cells enhance macrophage phagocytosis in the in vitro and in vivo models of ARDS. Stem Cells. 2016;34(8):2210-23.

149. Hsu YC, Wu YT, Yu TH, Wei YH. Mitochondria in mesenchymal stem cell biology and cell therapy: from cellular differentiation to mitochondrial transfer. Semin Cell Dev Biol. 2016;52:119-31.

150. Aguilera-Aguirre L, Bacsi A, Saavedra-Molina A, Kurosky A, Sur S, Boldogh I. Mitochondrial dysfunction increases allergic airway inflammation. J Immunol. 2009;183(8):5379-87.

151. Brealey D, Brand M, Hargreaves I, Heales S, Land J, Smolenski R, et al. Association between mitochondrial dysfunction and severity and outcome of septic shock. Lancet. 2002;360(9328):219-23.

152. Aravamudan B, Thompson MA, Pabelick CM, Prakash YS. Mitochondria in lung diseases. Expert Rev Respir Med. 2013;7(6):631-46.

153. Kiriyama Y, Nochi H. Intra- and intercellular quality control mechanisms of mitochondria. Cells. 2017;7(1).

154. Islam MN, Das SR, Emin MT, Wei M, Sun L, Westphalen K, et al. Mitochondrial transfer from bone-marrow-derived stromal cells to pulmonary alveoli protects against acute lung injury. Nat Med. 2012;18(5):759-65.

155. Phinney DG, Di Giuseppe M, Njah J, Sala E, Shiva S, St Croix CM, et al. Mesenchymal stem cells use extracellular vesicles to outsource mitophagy and shuttle microRNAs. Nat Commun. 2015;6:8472.

156. Cerri C, Chimenti D, Conti I, Neri T, Paggiaro P, Celi A. Monocyte/macrophage-derived microparticles up-regulate inflammatory mediator synthesis by human airway epithelial cells. J Immunol. 2006;177(3):1975-80.

157. Neri T, Scalise V, Passalacqua I, Giusti I, Lombardi $\mathrm{S}$, Balia $\mathrm{C}$, et al. CD18-mediated adhesion is required for the induction of a proinflammatory phenotype in lung epithelial cells by mononuclear cell-derived extracellular vesicles. Exp Cell Res. 2018;365(1):78-84.

158. Shentu TP, Huang TS, Cernelc-Kohan M, Chan J, Wong SS, Espinoza CR, et al. Thy-1 dependent uptake of mesenchymal stem cell-derived extracellular vesicles blocks myofibroblastic differentiation. Sci Rep. 2017;7(1):18052.

159. Ragni E, Banfi F, Barilani M, Cherubini A, Parazzi V, Larghi P, et al. Extracellular vesicle-shuttled mRNA in mesenchymal stem cell communication. Stem Cells. 2017;35(4):1093-105.

160. Yanez-Mo M, Siljander PR, Andreu Z, Zavec AB, Borras FE, Buzas EI, et al. Biological properties of extracellular vesicles and their physiological functions. J Extracell Vesicles. 2015;4:27066.

161. Song Y, Dou H, Li X, Zhao X, Li Y, Liu D, et al. Exosomal miR-146a contributes to the enhanced therapeutic efficacy of interleukin-1beta-primed mesenchymal stem cells against sepsis. Stem Cells. 2017;35(5):1208-21.

162. Mokarizadeh A, Delirezh N, Morshedi A, Mosayebi G, Farshid AA, Mardani K. Microvesicles derived from mesenchymal stem cells: potent organelles for induction of tolerogenic signaling. Immunol Lett. 2012;147(1-2):47-54.

163. Kim YS, Kim JY, Cho R, Shin DM, Lee SW, Oh YM. Adipose stem cell-derived nanovesicles inhibit emphysema primarily via an FGF2-dependent pathway. Exp Mol Med. 2017;49(1):e284.

164. Matthay MA, Calfee CS, Zhuo H, Thompson BT, Wilson JG, Levitt JE, et al. Treatment with allogeneic mesenchymal stromal cells for moderate to severe acute respiratory distress syndrome (START study): a randomised phase 2 a safety trial. Lancet Respir Med. 2018.

165. Tzouvelekis A, Paspaliaris V, Koliakos G, Ntolios $\mathrm{P}$, Bouros E, Oikonomou A, et al. A prospective, non-randomized, no placebo-controlled, phase Ib clinical trial to study the safety of the adipose derived stromal cells-stromal vascular fraction in idiopathic pulmonary fibrosis. J Transl Med. 2013;11:171

166. Chambers DC, Enever D, Ilic N, Sparks L, Whitelaw $\mathrm{K}$, Ayres J, et al. A phase 1b study of placentaderived mesenchymal stromal cells in patients with idiopathic pulmonary fibrosis. Respirology. 2014;19(7):1013-8.

167. Zheng G, Huang L, Tong H, Shu Q, Hu Y, Ge M, et al. Treatment of acute respiratory distress syndrome with allogeneic adipose-derived mesenchymal stem cells: a randomized, placebo-controlled pilot study. Respir Res. 2014;15:39.

168. Skrahin A, Ahmed RK, Ferrara G, Rane L, Poiret T, Isaikina $\mathrm{Y}$, et al. Autologous mesenchymal stromal cell infusion as adjunct treatment in patients with multidrug and extensively drug-resistant tuberculosis: an open-label phase 1 safety trial. Lancet Respir Med. 2014;2(2):108-22. 
169. Li X, Zhang Y, Yeung SC, Liang Y, Liang X, Ding $\mathrm{Y}$, et al. Mitochondrial transfer of induced pluripotent stem cell-derived mesenchymal stem cells to airway epithelial cells attenuates cigarette smokeinduced damage. Am J Respir Cell Mol Biol. 2014;51(3):455-65.

170. Zhao Y, Xu A, Xu Q, Zhao W, Li D, Fang X, et al. Bone marrow mesenchymal stem cell transplantation for treatment of emphysemic rats. Int J Clin Exp Med. 2014;7(4):968-72.

171. Guan XJ, Song L, Han FF, Cui ZL, Chen X, Guo $\mathrm{XJ}$, et al. Mesenchymal stem cells protect cigarette smoke-damaged lung and pulmonary function partly via VEGF-VEGF receptors. J Cell Biochem. 2013;114(2):323-35.

172. Li Y, Gu C, Xu W, Yan J, Xia Y, Ma Y, et al. Therapeutic effects of amniotic fluid-derived mesenchymal stromal cells on lung injury in rats with emphysema. Respir Res. 2014;15:120.

173. Polchert D, Sobinsky J, Douglas G, Kidd M, Moadsiri A, Reina E, et al. IFN-gamma activation of mesenchymal stem cells for treatment and prevention of graft versus host disease. Eur J Immunol. 2008;38(6):1745-55.

174. Ren G, Su J, Zhang L, Zhao X, Ling W, L'Huillie A, et al. Species variation in the mechanisms of mesenchymal stem cell-mediated immunosuppression. Stem Cells. 2009;27(8):1954-62.

175. Romieu-Mourez R, Francois M, Boivin MN, Bouchentouf M, Spaner DE, Galipeau J. Cytokine modulation of TLR expression and activation in mesenchymal stromal cells leads to a proinflammatory phenotype. J Immunol. 2009;182(12):7963-73.

176. Xu LL, Fu HX, Zhang JM, Feng FE, Wang QM, Zhu $\mathrm{XL}$, et al. Impaired function of bone marrow mesenchymal stem cells from immune thrombocytopenia patients in inducing regulatory dendritic cell differentiation through the Notch-1/Jagged-1 signaling pathway. Stem Cells Dev. 2017;26(22):1648-61.

177. Francois M, Romieu-Mourez R, Li M, Galipeau J. Human MSC suppression correlates with cytokine induction of indoleamine 2,3-dioxygenase and bystander M2 macrophage differentiation. Mol Ther. 2012;20(1):187-95.

178. Francois M, Romieu-Mourez R, Stock-Martineau S, Boivin MN, Bramson JL, Galipeau J. Mesenchymal stromal cells cross-present soluble exogenous antigens as part of their antigen-presenting cell properties. Blood. 2009;114(13):2632-8.

179. Chan JL, Tang KC, Patel AP, Bonilla LM, Pierobon $\mathrm{N}$, Ponzio NM, et al. Antigen-presenting property of mesenchymal stem cells occurs during a narrow window at low levels of interferon-gamma. Blood. 2006;107(12):4817-24.

180. Bustos ML, Huleihel L, Meyer EM, Donnenberg AD, Donnenberg VS, Sciurba JD, et al. Activation of human mesenchymal stem cells impacts their therapeutic abilities in lung injury by increasing interleukin (IL)-10 and IL-1RN levels. Stem Cells Trans1 Med. 2013;2(11):884-95.
181. Abreu SC, Xisto DG, de Oliveira TB, Blanco NG, de Castro LL, Kitoko JZ, et al. Serum from asthmatic mice potentiates the therapeutic effects of mesenchymal stromal cells in experimental allergic asthma. Stem Cells Transl Med. 2019;8(3):301-12. https:// doi.org/10.1002/sctm.18-0056. Epub 2018 Nov 13.

182. Zhao X, Liu D, Gong W, Zhao G, Liu L, Yang L, et al. The toll-like receptor 3 ligand, poly(I:C), improves immunosuppressive function and therapeutic effect of mesenchymal stem cells on sepsis via inhibiting MiR-143. Stem Cells. 2014;32(2):521-33.

183. Hu X, Yu SP, Fraser JL, Lu Z, Ogle ME, Wang JA, et al. Transplantation of hypoxia-preconditioned mesenchymal stem cells improves infarcted heart function via enhanced survival of implanted cells and angiogenesis. J Thorac Cardiovasc Surg. 2008;135(4):799-808.

184. Fehrer C, Brunauer R, Laschober G, Unterluggauer $\mathrm{H}$, Reitinger S, Kloss F, et al. Reduced oxygen tension attenuates differentiation capacity of human mesenchymal stem cells and prolongs their lifespan. Aging Cell. 2007;6(6):745-57.

185. Mangi AA, Noiseux N, Kong D, He H, Rezvani M, Ingwall JS, et al. Mesenchymal stem cells modified with Akt prevent remodeling and restore performance of infarcted hearts. Nat Med. 2003;9(9):1195-201.

186. Chen S, Chen X, Wu X, Wei S, Han W, Lin J, et al. Hepatocyte growth factor-modified mesenchymal stem cells improve ischemia/reperfusioninduced acute lung injury in rats. Gene Ther. 2017;24(1):3-11.

187. Song H, Kwon K, Lim S, Kang SM, Ko YG, Xu $\mathrm{Z}$, et al. Transfection of mesenchymal stem cells with the FGF-2 gene improves their survival under hypoxic conditions. Mol Cells. 2005;19(3):402-7.

188. Jiang S, Haider H, Idris NM, Salim A, Ashraf M. Supportive interaction between cell survival signaling and angiocompetent factors enhances donor cell survival and promotes angiomyogenesis for cardiac repair. Circ Res. 2006;99(7):776-84.

189. Mei SH, McCarter SD, Deng Y, Parker CH, Liles WC, Stewart DJ. Prevention of LPS-induced acute lung injury in mice by mesenchymal stem cells overexpressing angiopoietin 1. PLoS Med. 2007;4(9):e269.

190. McGinley LM, McMahon J, Stocca A, Duffy A, Flynn A, O'Toole D, et al. Mesenchymal stem cell survival in the infarcted heart is enhanced by lentivirus vector-mediated heat shock protein 27 expression. Hum Gene Ther. 2013;24(10):840-51.

191. Baldari S, Di Rocco G, Trivisonno A, Samengo D, Pani G, Toietta G. Promotion of survival and engraftment of transplanted adipose tissue-derived stromal and vascular cells by overexpression of manganese superoxide dismutase. Int J Mol Sci. 2016;17(7).

192. He H, Liu L, Chen Q, Liu A, Cai S, Yang Y, et al. Mesenchymal stem cells overexpressing angiotensin-converting enzyme 2 rescue 
lipopolysaccharide-induced lung injury. Cell Transplant. 2015;24(9):1699-715.

193. Madonna R, Rinaldi L, Rossi C, Geng YJ, De Caterina R. Prostacyclin improves transcoronary myocardial delivery of adipose tissue-derived stromal cells. Eur Heart J. 2006;27(17):2054-61.

194. Assmus B, Walter DH, Seeger FH, Leistner DM, Steiner J, Ziegler I, et al. Effect of shock wave-facilitated intracoronary cell therapy on LVEF in patients with chronic heart failure: the CELLWAVE randomized clinical trial. JAMA. 2013;309(15):1622-31.

195. Retuerto MA, Schalch P, Patejunas G, Carbray J, Liu N, Esser K, et al. Angiogenic pretreatment improves the efficacy of cellular cardiomyoplasty performed with fetal cardiomyocyte implantation. J Thorac Cardiovasc Surg. 2004;127(4):1041-9.. discussion 9-51

196. Broekman W, Khedoe P, Schepers K, Roelofs H, Stolk J, Hiemstra PS. Mesenchymal stromal cells: a novel therapy for the treatment of chronic obstructive pulmonary disease? Thorax. 2018;73(6):565-74.

197. Gunilla W-T, Bjermer LH, Oskar H. Extracellular matrix remodelling in COPD. Eur Med J. 2014:1-6.

198. Fragoso E, Andre S, Boleo-Tome JP, Areias V, Munha J, Cardoso J, et al. Understanding COPD: a vision on phenotypes, comorbidities and treatment approach. Rev Port Pneumol. 2016;22(2):101-11.

199. Welte T, Vogelmeier C, Papi A. COPD: early diagnosis and treatment to slow disease progression. Int J Clin Pract. 2015;69(3):336-49.

200. Galipeau J, Krampera M, Barrett J, Dazzi F, Deans RJ, DeBruijn J, et al. International society for cellular therapy perspective on immune functional assays for mesenchymal stromal cells as potency release criterion for advanced phase clinical trials. Cytotherapy. 2016;18(2):151-9.

201. Galipeau J, Krampera M. The challenge of defining mesenchymal stromal cell potency assays and their potential use as release criteria. Cytotherapy. 2015;17(2):125-7.

202. Sand JM, Martinez G, Midjord AK, Karsdal MA, Leeming DJ, Lange P. Characterization of serological neo-epitope biomarkers reflecting collagen remodeling in clinically stable chronic obstructive pulmonary disease. Clin Biochem. 2016;49(15):1144-51.

203. Sand JM, Leeming DJ, Byrjalsen I, Bihlet AR, Lange P, Tal-Singer R, et al. High levels of biomarkers of collagen remodeling are associated with increased mortality in COPD - results from the ECLIPSE study. Respir Res. 2016;17(1):125.

204. Sand JM, Knox AJ, Lange P, Sun S, Kristensen JH, Leeming DJ, et al. Accelerated extracellular matrix turnover during exacerbations of COPD. Respir Res. 2015;16:69.

205. Dominici M, Nichols K, Srivastava A, Weiss DJ, Eldridge P, Cuende N, et al. Positioning a scientific community on unproven cellular therapies: the 2015 International Society for Cellular Therapy Perspective. Cytotherapy. 2015;17(12):1663-6.

206. Dominici M, Nichols KM, Levine AD, Rasko JE, Forte M, O'Donnell L, et al. Science, ethics and communication remain essential for the success of cell-based therapies. Brain Circ. 2016;2(3):146-51.

207. Ikonomou L, Panoskaltsis-Mortari A, Wagner DE, Freishtat RJ, Weiss DJ, American Thoracic Society Respiratory C, et al. Unproven stem cell treatments for lung disease-an emerging public health problem. Am J Respir Crit Care Med. 2017;195(7):P13-P4.

208. Marks P, Gottlieb S. Balancing safety and innovation for cell-based regenerative medicine. N Engl J Med. 2018;378(10):954-9.

209. ATS RCMB Stem Cell Working Group. Statement on unproven stem cell interventions for lung diseases. New York: American Thoracic Society; $2016 .$. (Available from: https://www.thoracic.org/members/ assemblies/assemblies/rcmb/working-groups/stemcell/resources/statement-on-unproven-stem-cellinterventions-for-lung-diseases.pdf).

210. Weiss DJ, Turner L, Levine AD, Ikonomou L. Medical societies, patient education initiatives, public debate and marketing of unproven stem cell interventions. Cytotherapy. 2018;20(2):165-8.

211. Wagner DE, Turner L, Panoskaltsis-Mortari A, Weiss DJ, Ikonomou L. Co-opting of ClinicalTrials. gov by patient-funded studies. Lancet Respir Med. 2018;6(8):579-81.

212. Ikonomou L, Freishtat RJ, Wagner DE, PanoskaltsisMortari A, Weiss DJ. The global emergence of unregulated stem cell treatments for respiratory diseases. Professional societies need to act. Ann Am Thorac Soc. 2016;13(8):1205-7. 